\title{
College dating and social anxiety: Using the Internet as a means of connecting to others
}

\author{
Sarah B. Stevens \\ West Virginia University
}

Follow this and additional works at: https://researchrepository.wvu.edu/etd

\section{Recommended Citation}

Stevens, Sarah B., "College dating and social anxiety: Using the Internet as a means of connecting to others" (2006). Graduate Theses, Dissertations, and Problem Reports. 4271.

https://researchrepository.wvu.edu/etd/4271

This Thesis is protected by copyright and/or related rights. It has been brought to you by the The Research Repository @ WVU with permission from the rights-holder(s). You are free to use this Thesis in any way that is permitted by the copyright and related rights legislation that applies to your use. For other uses you must obtain permission from the rights-holder(s) directly, unless additional rights are indicated by a Creative Commons license in the record and/ or on the work itself. This Thesis has been accepted for inclusion in WVU Graduate Theses, Dissertations, and Problem Reports collection by an authorized administrator of The Research Repository @ WVU. For more information, please contact researchrepository@mail.wvu.edu. 
College Dating and Social Anxiety: Using the Internet as a Means of Connecting to Others

Sarah B. Stevens

\author{
Thesis submitted to the \\ Eberly College of Arts and Sciences \\ at West Virginia University \\ in partial fulfillment of the requirements \\ for the degree of
}

\author{
Master of Science \\ in \\ Psychology
}

\author{
Tracy L. Morris, Ph.D., Chair \\ Cheryl B. McNeil, Ph.D. \\ Julie H. Patrick, Ph.D. \\ Department of Psychology \\ Morgantown, West Virginia \\ 2006
}

Keywords: Social anxiety, dating anxiety, young adults, Internet, computer use 


\section{ABSTRACT}

College Dating and Social Anxiety: Using the Internet as a Means of Connecting to Others

\section{Sarah B. Stevens}

With the advent and widespread use of the Internet, various online media are being used to connect and maintain social relationships in individuals of all ages. Social relationships are vital to healthy development, and individuals with social and/or dating anxiety may have marked difficulty in establishing appropriate, supportive relationships due to fear of negative evaluation by others. For these individuals, the Internet may open up avenues of communication, and provide an outlet through which relationships can be formed and preserved. This study investigated the characteristics of computer and Internet use in young adults, to determine whether individuals who were high in social/dating anxiety symptoms were more likely to make and maintain social relationships online. To further understand the patterns of these behaviors, several measures of social and dating anxiety were collected and analyzed along with demographic, computer use, and relationship characteristics. Results indicated differences between high and low social/dating anxiety with respect to media use and relationship formation. Limitations and future directions are discussed. 


\section{Acknowledgements}

I am truly grateful for all of the help and support I have received from my family, friends, and colleagues over the past three years.

To my committee, Dr. Cheryl McNeil and Dr. Julie Patrick. I am very fortunate to have such supportive and encouraging committee. Your assistance has been invaluable and I am eternally in your debt!

To my advisor and committee chair, Dr. Tracy Morris. I am honored to have worked with you and can't express my gratitude and respect for all that you have done to help me with this project and in general. I am proud to have worked with such an outstanding woman.

To my sisters, Sydney and Anne. You are my best friends and I cannot imagine my life without you! Thank you for being my sounding boards and my support system. I love you both with all of my heart.

And to my parents, Robert and Carol Stevens. I am truly blessed to have you in my life and as my parents. Words cannot express how much I love and admire you both. You have given me so much and I am honored to be your daughter. Thank you so much!

In Loving Memory of Joan Stevens

$1919-2006$ 


\section{Table of Contents}

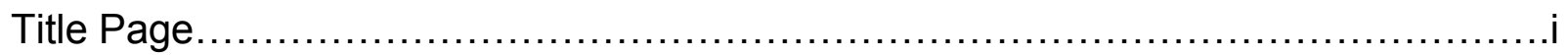

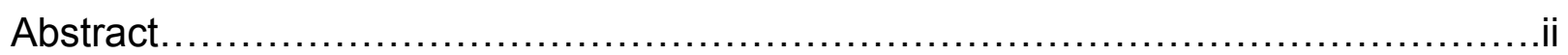

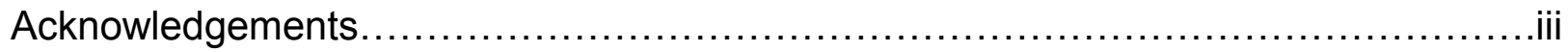

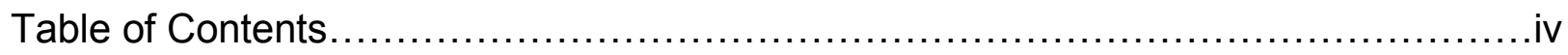

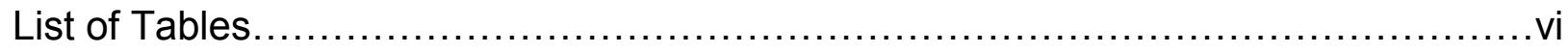

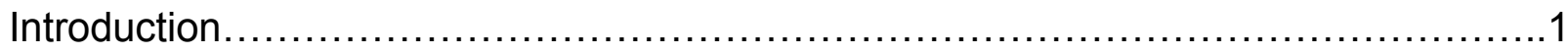

Use of the Internet as a communication tool......................................

Use of the Internet in a socially anxious college population.........................

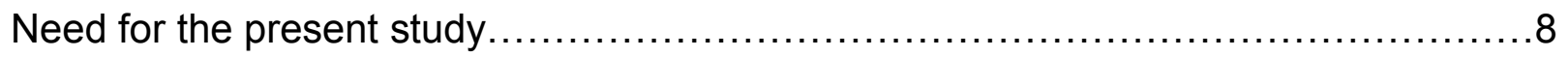

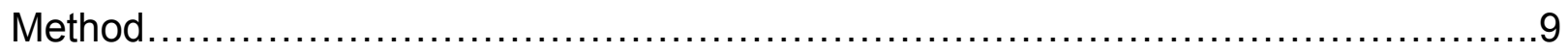

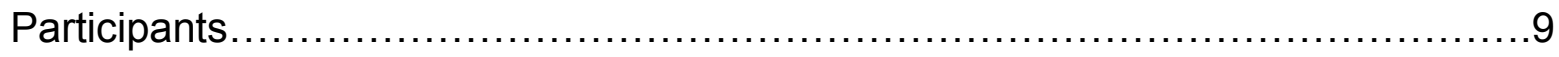

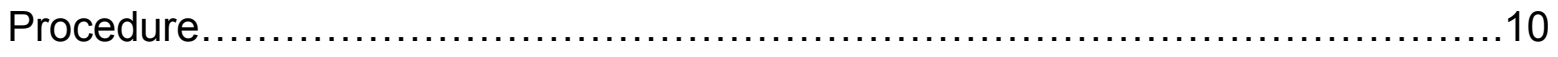

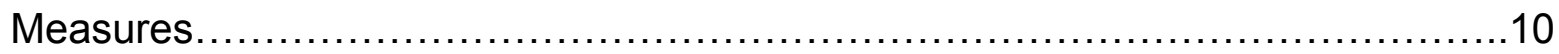

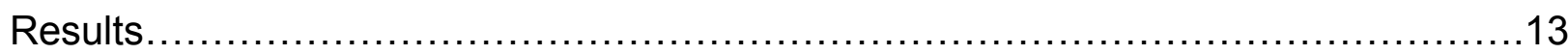

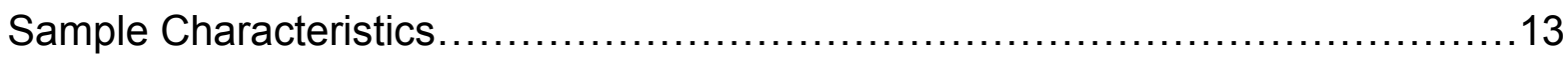

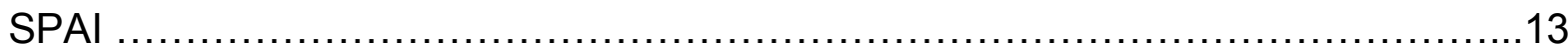

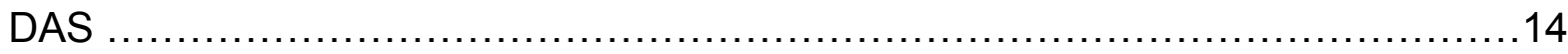

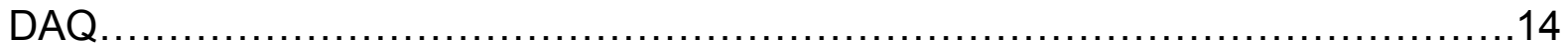

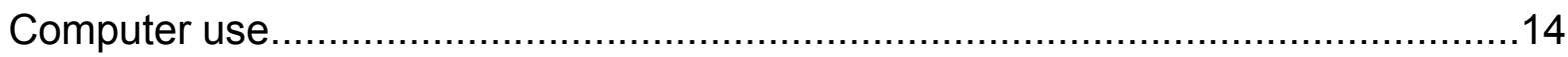

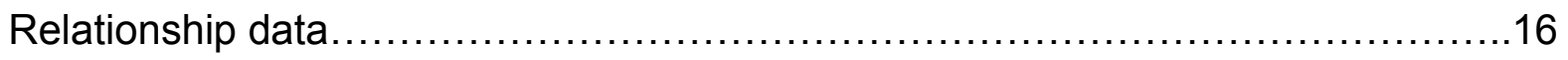




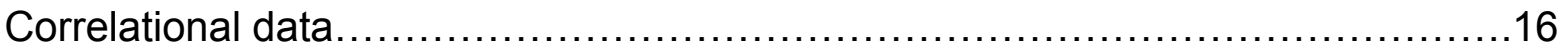

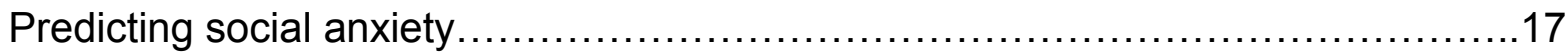

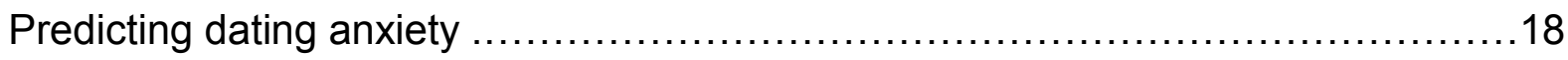

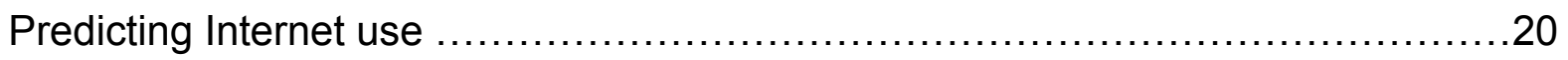

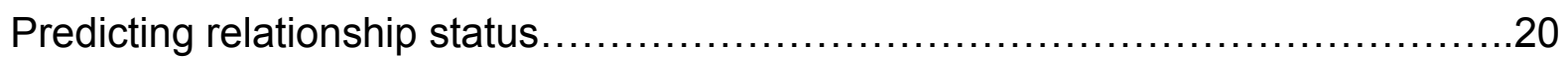

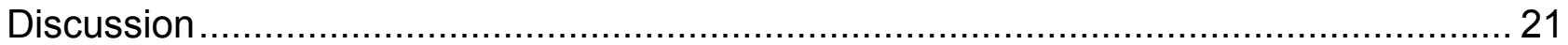

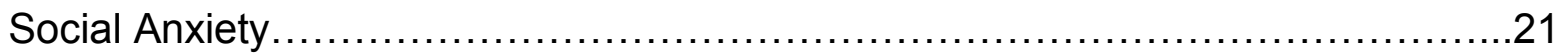

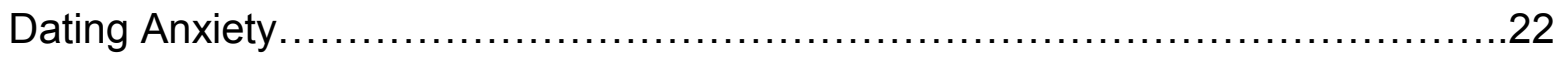

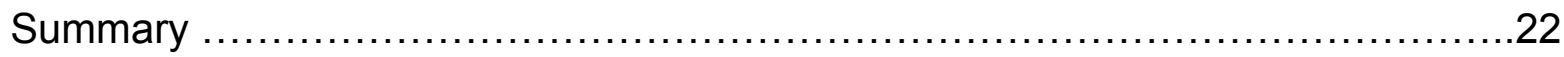

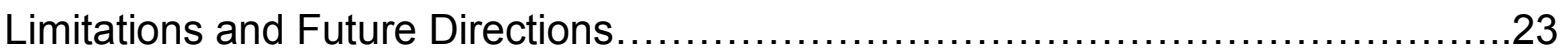

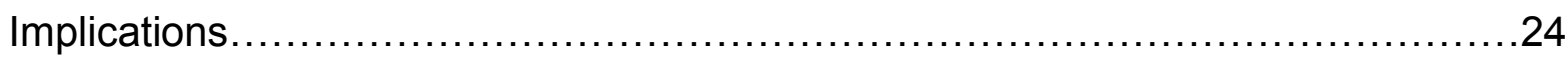

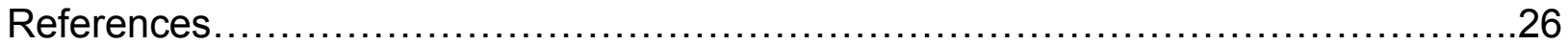




\section{List of Tables}

Table 1. Demographic Characteristics of the Full Sample and Male and Female Participants. 31

Table 2. Computer Use Statistics of the Full Sample and Male and Female Participants.... 32

Table 3. Intercorrelation Matrix of Demographic Variables Between High and Low Social Anxiety Groups 33

Table 4. Intercorrelation Matrix of Computer Use Variables (Media used to maintain online relationship) Between High and Low Social Anxiety Groups

34

Table 5. Intercorrelation Matrix of Relationship Variables and Social/Dating Anxiety Measures Between High and Low Social Anxiety Groups 35

Table 6. Intercorrelation Matrix of Demographic Variables and Computer Use Variables (Media used to maintain online relationship) Between High and Low Social Anxiety Groups 36

Table 7. Intercorrelation Matrix of Relationship Variables, Social/Dating Anxiety Measures, and Demographic Variables Between High and Low Social Anxiety Groups 37

Table 8. Intercorrelation Matrix of Relationship Variables, Social/Dating Anxiety Measures, and Computer Use Variables (Media used to maintain online relationship) 38

Table 9. Logistic Regression Results for SPAI score as Dependent Variable. 39

Table 10. Logistic Regression Results for DAQ score as Dependent Variable. 40 
Table 11. Logistic Regression Results for DAS score as Dependent Variable.......................................41

Table 12. Logistic Regression Results for Online Media as Dependent Variables....................................42

Table 13. Logistic Regression Results for Relationship Status as Dependent Variables......................................43

Table 14. Summary of Findings.............44 
College dating and social anxiety: Using the internet as a means of connecting to others

The Internet is arguably one of the most important and technologically advanced inventions of our time. It connects the world to vast amounts of information with just the touch of a button; people in every corner of the globe can get up to date news on current events, weather changes, and a myriad of other things. The advent of the computer age, coupled with the enormity of information available on the Internet has enabled young and old to access many areas of knowledge. Due to increases in computer ownership as well as reductions in online service fees, the Internet has become progressively more available for most people in the United States. According to Internet World Statistics (2005), over 218 million people in North America have and use Internet access, an increase of $102 \%$ since the year 2000 . Approximately $66 \%$ of adults go online, with females and males equally as likely to use the Internet (65\% vs. $66 \%$ ). There are racial/ethnic and socio-economic differences in Internet usage: $68 \%$ of Caucasian individuals use the Internet regularly versus $51 \%$ of African American individuals, and use increases from $48 \%$ in households with an income of less than $\$ 30,000$ a year to $92 \%$ in households with an income of greater than $\$ 75,000$. Age is also a factor in Internet usage; the two largest age groups for online usage are children under the age of 18 and college-aged adults, with $97 \%$ and $81 \%$ of persons, respectively, going online (Pew Internet and American Life Study, 2005; UCLA Internet Report, 2002). Not surprising when we consider that these cohorts have never lived in a world without the Internet. The number of hours spent online has risen for all ages in the past few years, from an average of 9.4 hours per week in 2000 to 11.1 in 2002 (UCLA Internet Report, 2002). 
Use of the Internet as a communication tool. One of the greatest contributions of the Internet is its substantial impact in the area of communication (Kraut et al., 2002; Pew Internet and American Life Study, 2005). Through its use, people are able to keep in touch with one another in real time; one can send letters, photos, even videos to family and friends near and far. The Internet has connected us in ways that we are only just beginning to understand; individuals that may only be able to see each other face to face a few times a year are now able to keep in close contact. It is no wonder that we have dubbed it the "world wide web;" it connects us together despite great distances. A variety of media exist on the web for people to use in maintaining ties with others. In the year 2004 , over $90 \%$ of people who used the Internet utilized electronic mail, otherwise known as e-mail, making it the most popular communication medium (Pew Internet and American Life Project, 2005). However, other online services are fast becoming increasingly popular forms of interaction. These services include instant messaging (IM), chat rooms, web cams, web logs (blogs), bulletin boards, and online personal dating services. In order to remain connected to those we know, or even meet those we wish to know, we have expanded our traditional behavioral repertoires to include the new and increasingly common online media. According to the Pew Internet Report and the American Life Project, $42 \%$ of Internet users stated that they had utilized IM, with $14 \%$ stating that they used IM daily; $27 \%$ endorsed reading "blogs," while $7 \%$ stated that they had created a "blog" of their own; $25 \%$ acknowledged participating in chat room discussions, with $4 \%$ chatting daily; and $9 \%$ stated that they had used online dating sites. These figures are the result of random digit dialing and online surveys. Other reports have shown that up to 34 million people have visited online dating sites, the 
most popular and well-known being Match.com, Yahoo! Personals, and e-Harmony.com (Sullivan, 2002).

With the large swell in Internet usage, there has been some controversy regarding whether the Internet has actually helped us to become more social and establish closer relationships. Kraut et al. (1998) reported several negative effects of the dramatic increase in Internet use. The authors stated that while the Internet should, in theory, improve existing relationships by increasing social involvement and forming new relationships, it has been shown to have a negative effect on so called "heavy" users who become "paradoxically" less socially involved, lonelier, and more likely to endorse depressive symptoms. Though the initial study was criticized for lacking a control group, a subsequent follow-up study of 208 of the original 335 respondents found that the negative effects had lessened (Kraut et al., 2002). As a caveat, though, the authors stated that the positive effects of Internet use were larger for extroverts than introverts; specifically, extroverts who had high Internet usage were more likely to report greater community involvement, while introverts with high Internet usage were more likely to report lesser community involvement. Similarly, a study by Morahan-Martin and Schumacher (2003) showed that individuals high in loneliness were more likely to use the Internet and e-mail as a means of connecting to others than non-lonely individuals. Lonely individuals also were more likely to show negative effects in daily functioning as a result of high levels of Internet use.

Despite some studies to the contrary (Kraut et al., 1998; Wästlund, Norlander, \& Archer, 2001), several studies have shown that a large percentage of people feel that the Internet has enriched their social connectedness (Chen, \& Persson, 2002; UCLA 
Internet Report, 2002). According to the UCLA Internet Report (2002), 48.7\% of people strongly agreed that the Internet allows them to connect better with family and friends and $50.9 \%$ stated that the internet had increased the number of people with whom they stayed in contact. With the myriad of communication media available on the Internet, it is easy to see how people can connect with known friends or even meet others, despite distance, location, and time.

Use of the Internet in a socially-anxious college population. College is a time of dramatic change in the lives of young adults (Berzonsky, \& Kuk, 2000; Ponzetti, 1990; Wilcox, Winn, \& Fyvie-Gauld, 2005). Many teens must begin a new life away from home, with increased responsibility for themselves and their schoolwork. Changes in social situations are common place as well: whereas in high school there was an intact social circle of friends, in college, many students may have to make new friends in a new area, or find that friends so close in high school become strangers in college. For those with no difficulty in social situations, this time is one of excitement and wonder. The chance to meet others, either in platonic or romantic relationships, or reinvent a persona in college is an exciting and wonderful idea. But for individuals with social or dating anxiety, the process can become terrifying. These individuals may become further isolated, having to move to a new place without the safety of established social circles. Social anxiety is defined as the fear of negative evaluations by others in social situations, while dating anxiety is defined as apprehension and discomfort in interactions with a potential romantic partner (APA, 2000; Hope \& Heimberg, 1990). Both of these conditions are marked by fear and anxiety of such situations, and often result in avoidance of social and/or dating scenarios, making it difficult to connect in 
reinforcing social engagements. Socially-anxious individuals often are characterized by low numbers of close friends and acquaintances. Despite the desires to meet and engage in platonic or romantic relationships, socially-anxious individuals often are unable to make the necessary effort for fear of negative evaluation by others.

The lack of romantic and platonic attachments also may be a significant factor in the development of other social and mental health problems. Individuals with severe social and/or dating anxiety may be more likely to experience distress in other areas as a result of insufficient interpersonal relationships. Davila and Beck (2002) examined the association between social anxiety and other areas of impairment and found that social anxiety symptoms significantly correlated with symptoms of depression, as well as with over reliance on others and increased interpersonal stress. They also found that individuals with higher social anxiety symptoms were more likely to avoid expressing strong emotions, and report a desire to avoid conflict. These associations were found even after controlling for depression. Additionally, individuals with social/dating anxiety may be more likely to report loneliness in their daily lives. There has been substantial linkage between the two constructs; researchers have reported correlations from .41 to .50 (Anderson \& Arnoult, 1985; Jones et al., 1986). Loneliness is described by Morahan-Martin (1999) as a "discrepancy between the[ir] desired and achieved level of social interaction, support, and intimacy." Increased levels of loneliness have been associated with depression, anxiety, and substance abuse (Booth, 2000). In looking at an adolescent population, La Greca and Harrison (2005) found that individuals who were not dating were higher in social anxiety than those who were currently in a relationship. Himadi et al. (1980) examined minimal dating and its association to other 
social problems and found that men who engaged in lower rates of dating showed deficiencies in same-sex relationships, as well.

However, with the advent of the Internet and its numerous communication services, many people are using the web as a potential avenue to find romantic and platonic partners. Donn and Sherman (2002) found that $7.7 \%$ of college students and $19.7 \%$ of graduate students had taken steps to meet a potential romantic partner online. Knox, Daniels, Sturdivant, and Zusman (2001) found that $40 \%$ of their college sample had used the Internet to gain and establish new friendships, while 7\% reported becoming romantically involved with a person they met online. This study also showed that the major function behind Internet use was anxiety reduction, with respondents stating that they felt less shy online than in person. These studies suggest that persons with social or dating anxiety have a potential avenue by which to explore the relationships they desire in a less threatening manner than the traditional face-to-face interactions that others may use. Some research already has suggested that individuals with social anxiety may be more inclined to seek out personal relationships over the Internet. Ward and Tracey (2004) found that individuals high in shyness were more likely to become involved in online relationships. In her unpublished dissertation research, McKenna (1999) found that socially-anxious people were more likely to use the Internet to form relationships, and that these relationships typically developed more quickly than their face-to-face counter parts. In a survey of over 600 internet newsgroups and 2 laboratory studies conducted at Ohio University, the author found that due to so-called "gating features" inherent in the face-to-face meeting process, many individuals with performance or evaluation anxiety were more likely to use the 
internet as a means to connect to others. Gating features include physical appearance variables, such as height and weight, as well as other aspects of personality, speech, and self-presentation that may hinder the initial positive evaluation by a potential partner or friend. These gating features may be of particular concern for individuals with social anxiety, as they may perceive the physiological characteristics associated with their distress, such as shaking, sweating, and blushing, as off-putting or negatively evaluated by others. Individuals who use the Internet to obtain or maintain relationships may feel more at ease conducting the initial phases of a relationship online, where the gating features are not as salient. Depending upon the level of anxiety associated with their personal aspects, they may be more or less accurate in their description. For example, a person who is highly anxious or critical of their height or weight may choose to be inaccurate in their description as a way of advancing an online relationship. In a later study expanding upon her findings, McKenna and her colleagues found that the more people portrayed their "true self" online, the more likely they were to meet their partner face-to-face (McKenna, Green, \& Gleason, 2002). Twenty Usenet groups were randomly selected, although "personals" and "pen pals" newsgroups were removed to control for individuals who were deliberately seeking relationships. A 36-item survey was used to assess level of anxiety and relationship formation variables (expression of "real self," type and depth of relationship formed, and behavioral actions), including six items from the Leary's Interaction Anxiousness Scale and five items from the UCLA Loneliness Scale.

There is evidence that there may be a large number of individuals online with social anxiety. Erwin et al. (2004) found that individuals who responded online to a 
survey of social phobia symptomatology had greater levels of severity and impairment than a treatment-seeking sample, suggesting that some were so severe they were unable or unwilling to seek treatment for their problems, or that answering questions online increases symptom reporting. This information, coupled with the variety of media available for communication begs the question, what type of media are socially anxious individuals most likely to utilize in beginning online relationships?

Need for the Present Study

Social support and interaction is a crucial part of everyday life, even more so in the critical college years (Calsyn, Winter, \& Burger, 2005; Largo-Wight, Peterson, Chen, 2005; Mallinckrodt, \& Wei, 2005). The present study seeks to examine current college dating practices and the use of Internet communication media by individuals with and without social anxiety. Very little is known about current dating practices in college samples, especially in light of the dramatic increases in Internet access and use in recent years. First, one must gain an understanding of the current methods and practices being used by a college population to establish romantic and platonic relationships. Then, one must ascertain the rate of computer usage, for both general uses such as class work, and for personal communication. By rating a person's level of social and dating anxiety, one can examine the ways in which these individuals differ from non-anxious controls in terms of usage, type of media, etc. After establishing the cutoff level for high and low social and dating anxiety, we may examine the types of media, if any, these individuals are using. By ascertaining what online methods are mostly likely to be used by individuals high in social anxiety, clinicians may be able to use the Internet as an exposure tool for clients presenting with social or dating anxiety. 
Of particular interest are the frequency, severity, and specificity of symptoms of social and/or dating anxiety with relation to aspects of Internet involvement.

The following hypotheses were tested:

H1: Individuals low on anxiety are more likely to meet others and engage in dating practices than individuals high in social and/or dating anxiety.

$H 2$ : Individuals high in social and/or dating anxiety are more likely to use the Internet to make and maintain romantic and platonic relationships than typical college students.

H3: Severity of anxiety symptoms is related to type or mode of involvement, with those most severe more likely to engage in media in which less personal identification is used.

H4: Severity of anxiety symptoms is related to whether or not a face-to-face meeting has occurred, with those most severe being less likely to have a real-life meeting.

Method

Participants

Participants were recruited from various undergraduate psychology classes at West Virginia University, including Introduction to Psychology, Human Development, and Social Psychology; approximately 2,000 students were enrolled in these classes, and were eligible for participation. The study was conducted in October of 2005, and was open for approximately one month. Seven hundred and eight participants were recruited; however, 40 participants were dropped due to being under the age of consent or over age 25. The final subject pool consisted of 666 (472 females and 194 males) 
participants, who were asked to complete survey and questionnaire data to gauge demographic information, computer use, and level of social and dating anxiety.

Procedure

Information about the study and its benefits was presented to various psychology classes, and participants were allowed to log in to a website to participate in the study. After receiving a log-in username and password for the SONA web system, participants were asked to fill out anonymous demographic, computer use, and relationship surveys, as well as several questionnaires regarding social and dating anxiety levels. Measures were presented in order from least to most intrusive or sensitive in nature. Completion of all measures took approximately 1 hour, and participants received extra credit for their participation in the study.

\section{Measures}

Demographic Questionnaire. A demographics questionnaire was created for use in this particular study. Surveys were given to gather information on age, sex, race/ethnicity, sexual orientation, and year in college. See Appendix A.

Computer/Internet Use Questionnaire. The Computer/Internet Use questionnaire was developed for this study to gain information about computer use, and Internet media use in particular. Questionnaires gathered information concerning: computer ownership; Internet access; amount of time spent on the Internet; level of use of Internet services such as e-mail, instant messaging, chat rooms, web logs, web cams, and online dating services; level of comfort with the previously listed media; number of relationships made online; type of relationships made online; face to face meetings which may have taken place with those met online, etc. Questions used specifically for 
analysis included: Question 30, (Have you ever made an online relationship?) which was used to gauge whether the participant had made a relationship online prior to seeing the person face to face; Question 31, (How many online relationships have you made?) to assess the number of individual relationships the participant had made online; Questions 31, 32, and 33, which assessed the nature of the online relationships; Question 34, (Did a face-to-face meeting result from this online relationship?) to determine whether the participant had met the online partner outside of the Internet; Questions 36, 37, and 38, which examined the online media used to make and maintain the online relationship; and questions 39 and 40 , which assessed other communication that may have occurred (i.e., telephone and snail mail). See Appendix B.

Friendship and Dating Practices Questionnaire. The Friendship and Dating Practices questionnaire was developed for this study to obtain information about participant relationships. The questionnaire gathered information concerning: participant's dating history; whether they have a significant other; length of relationship with significant other; how the participant met his/her significant other; opinion on the definition of a date; style of date most used; first-date practices; presence of a best or closest friend; how the participant met their best/closest friend, etc. Questions used specifically for analysis included: Question 1, (Have you ever been on a date?) which was used to gauge whether the participant had ever been on a date; Question 2, (Have you been on a date in the last 6 months?), which was used to assess current dating practices; and Question 3, (Do you have a significant other?), which was used to assess current romantic relationship status. See Appendix C. 
Social Phobia and Anxiety Index. (Turner, Beidel, Dancu, \& Stanley, 1989). The Social Phobia and Anxiety Index (SPAI) is a 45-item questionnaire that assesses level of anxiety with respect to social situations. Participants are asked to rate each statement on a scale from 0 (never) to 7 (always). Example statements include: "I feel anxious when approaching and/or initiating a conversation with strangers/authority figures/opposite sex/people in general," "I feel so anxious about attending social gatherings that I avoid these situations" and "I am not likely to speak to people unless they speak to me." The measure has demonstrated excellent test-retest reliability (.86), with an alpha of .96 for the social phobia subscale. Several studies have shown high discriminant and external validity (Beidel, Turner, Stanley, \& Dancu, 1989; Peters, 2000), as well as high concurrent validity with the Social Anxiety Scale $(r=.87)$, and the Fear Questionnaire ( $r=.92)$ (Davidson et al., 1991).

Dating Anxiety Survey. Developed by Calvert, Moore, and Jensen (1987), the Dating Anxiety Survey (DAS) assesses anxiety related to dating and romantic situations. The 23-item questionnaire has both male and female versions, although for the purposes of this study, it was modified in order to be applicable to gay, lesbian, and bi-sexual individuals. The survey is divided into three subscales: passive contact, dating interactions, and active interventions for dating. Previous studies have shown alphas that ranged from .87 to .93 for each subscale across male and female versions. The measure has demonstrated concurrent validity with other measures of dating and social anxiety. See Appendix D.

Dating and Assertion Questionnaire. (Levenson \& Gottman, 1978). The Dating and Assertion Questionnaire (DAQ) assesses social competence in dating interactions 
and situations, as well as situations for which assertive behavior is needed. The DAQ is an 18-item questionnaire divided into two subscales: a 9-item dating subscale and a 9item assertion subscale. For this study, only the dating subscale was used. The dating subscale provides examples of social situations and asks respondents to rate their competence, discomfort, and likelihood of behavior occurring on a scale from 1 (I never do this) to 4 (I do this almost always). Excellent internal consistency ( $\alpha=.92$ for the dating subscale) and test-retest reliability over a 4 week period $(r=.71$ for week 2 and $r$ $=.62$ for week 6) were noted by Levenson and Gottman (1978). See Appendix E.

\section{Results}

Sample Characteristics. The sample was composed of 472 female $(71 \%)$ and 194 male (29\%) respondents. The age of the respondents ranged between 18 and 24 years of age, with a mean age of 19 years. Demographic data are presented in Table 1.

SPAI. The overall mean of the SPAl for all 666 participants was 50.43 , with a standard deviation of 24.06 . For some of the analyses, SPAI scores were classified into high and low groups for use in binary logistic regression. Individuals who were rated "high" were those whose total SPAl scores placed them in the "Probable Social Phobia" (difference scores greater than or equal to 80 ) and "Possible Social Phobia" (difference scores between 60 and 79) ranges, while those rated "low" were individuals whose scores placed them in the "Social Phobia Unlikely" (difference scores less than 34) range. The mean of the "high" SPAl group $(\mathrm{N}=212)$ was 77.41 with a standard deviation of 14.76. The mean of the "low" group $(\mathrm{N}=160)$ was 20.06 with a standard deviation of 10.28 . 
DAS. The overall mean of the DAS for all 666 participants was 102.40 with a standard deviation of 24.14. For some of the analyses, DAS scores were classified into high and low groups for use in binary logistic regression. Using the $25^{\text {th }}$ and $75^{\text {th }}$ percentiles on the Dating Anxiety Survey, respondents were classified as "high" and "low" dating anxiety. The mean of the "high" DAS group $(\mathrm{N}=167)$ was 128.39 with a standard deviation of 8.34 , while the mean of the "low" dating anxiety group $(\mathrm{N}=179)$ was 69.34 with a standard deviation of 16.64 .

$D A Q$. The overall mean of the DAQ for all 666 participants was 26.87 with a standard deviation of 4.32. . For some of the analyses, DAQ scores were classified into high and low groups for use in binary logistic regression. Using the $25^{\text {th }}$ and $75^{\text {th }}$ percentiles on the Dating and Assertion Questionnaire, respondents were classified as "high" and "low" dating anxiety. The mean of the "high" dating anxiety group ( $N=181)$ was 21.59 with a standard deviation of 2.78 , while the mean of the "low" dating anxiety group $(\mathrm{N}=174)$ was 32.25 with a standard deviation of 2.19. Reverse scoring was used on the DAQ; thus a lower score indicated higher levels of dating anxiety.

Computer use. Approximately $98 \%$ of the sample stated that they both owned a computer and had access to the internet. Fifty-one percent of respondents reported spending one to three hours on the internet daily, while $11 \%$ reported less than one hour online, $25 \%$ reported spending three to five hours online, $9 \%$ reported spending five to seven hours per day, and $4 \%$ reported spending more than 7 hours per day. For individuals in the high social anxiety group, $50 \%$ reported spending one to three hours online per day, while $14 \%$ reported spending less than one hour, $22 \%$ reported spending three to five hours, $9 \%$ spending five to seven hours, and $6 \%$ spending more 
than seven hours. By contrast, $51 \%$ of the low anxiety group reported spending one to 3 hours online per day, while $11 \%$ reported spending less than one hour, $26 \%$ reported spending three to five hours, $8 \%$ reported spending five to seven hours and $5 \%$ spending more than seven hours per day online. A chi-square test was conducted to determine if there were differences between high and low social anxiety groups with regards to time spent online. The test was not significant, $\mathrm{X}^{2}(4)=1.08, p>.05$. Therefore, no differences were found between high and low social anxiety groups and time spent online.

Approximately $98 \%$ of the sample reported using electronic mail (email), with $51 \%$ checking email multiple times per day. Additional media use data (e.g., "Have you ever used IM?") are presented in Table 2. Respondents were asked to rate their experience and comfort level with the various media on a 5-point Likert scale. Females as a whole indicated that they were most experienced with email (90\%) and IM (87.7\%), and most comfortable using email (87.5\%) and IM (91.6\%). Similarly, males as a whole indicated that they were most experienced with email (89.7\%) and IM (90.7\%), and most comfortable with email (90.7\%) and IM (91.2\%).

With regard to the development of online relationships, $28.5 \%$ of respondents ( $28.8 \%$ of women and $27.8 \%$ of men) stated that they had made at least one online relationship. Of those who indicated an online relationship, approximately $31 \%$ stated that they made one, $18 \%$ reported making two, $16 \%$ reported making three, $30 \%$ reported making four or more, with $5 \%$ missing. The most common nature of the online relationship was Friend (47\%), with Acquaintance (37\%), Romantic Partner (10\%) and Close/Best Friend (5\%) also represented. Approximately $70 \%$ of those who made an 
online relationship indicated that a face-to-face meeting took place. The most common media used to maintain online relationships were IM (86\%), and email (6\%). Sixty-four percent of respondents indicated that they spoke on the telephone to the person with whom they had the online relationship.

Relationship data. Approximately $99 \%$ of the sample indicated that they had been on a date at some point in their lives, while $89.8 \%$ stated that they had been on a date in the last 6 months. Sixty-seven percent of women and $53 \%$ of men stated that they currently had a significant other. Twenty-five percent of respondents reported being in a relationship with their significant other for one to three years, while an additional $29 \%$ reported being in a relationship for less than a year. Only $2 \%$ of respondents stated that they had been in a relationship for more than 5 years.

Correlational data. Pearson correlations were conducted to assess the association between the demographic variables, the relationship variables, online media use variables and measures of social and dating anxiety between groups (i.e., high vs. low social anxiety). Correlational data for the demographic measures are presented in Table 3. A significant difference was found between the high and low groups in the correlation between sexual orientation and race/ethnicity, with the high social anxiety group being more highly correlated. Correlational data of online media variables are presented in Table 4. A significant difference was found between the high and low groups in the correlations between chat room and email use, email and webcam use, chat room and webcam use, blog and webcam use, and webcam and dating site use. Correlational data of relationship variables and measures of social/dating anxiety are presented in Table 5. A significant difference was found between the high and low 
groups in the correlations between ever been on a date and been on date in last 6 months, ever been on a date and DAQ score, date in the last 6 months and having a significant other, date in the last 6 months and DAQ score, SPAI score and DAQ score, and DAS score and making an online relationship. Correlational data of demographic and online media variables are presented in Table 6. A significant difference was found between the high and low groups in the correlation between year in school and IM use, and online dating site use and sexual orientation. Correlational data of demographic, relationship variables, and measures of social/dating anxiety are presented in Table 7. Correlational data of media use variables, relationship variables and measures of social/dating anxiety are presented in Table 8 . A significant difference was found between the high and low groups in the correlation between DAS score and IM use.

Predicting social anxiety. Chi square tests were conducted to examine the whether demographic variables, relationship variables, or media use variables were related to social anxiety. A significant relation was found between SPAI group and the use of blogs in online communication, $\mathrm{X}^{2}(1)=6.083, p<.05$. To examine predictors of social anxiety, binary logistic regression was conducted. First, demographic variables (year in school, gender, race, sexual orientation) were entered as predictors of scores on the SPAI. Approximately $58 \%$ were correctly classified. The high SPAI group contained 208 participants, and the low SPAI group contained 154. The overall model was not significant, $X^{2}(4)=4.432, p>.10$.

Second, making an online relationship was entered as a predictor of social anxiety status. The overall model was not significant, $X^{2}(1)=.488, p>.05$. Making an online relationship was not a unique predictor of social anxiety status. 
Third, media use variables (email, chat rooms, IM, blogs, webcams, online dating services, telephone, and snail mail; Questions 37, 39, and 40) were entered as predictors of social anxiety status. Fifty-seven percent were classified correctly; the high SPAI group contained 212 participants, while the low SPAI group contained 160 . The overall model was significant, $X^{2}(8)=20.043, p<.01$. Unique predictors were blog $(\beta=$ $-2.391, \mathrm{Wald}=4.631, \mathrm{OR}=.092,95 \% \mathrm{Cl}=.010-.808, p<.05)$ and webcam use $(\beta=$ 2.181, Wald $=4.065, \mathrm{OR}=8.852,95 \% \mathrm{Cl}=1.063-73.740, p<.05)$. Thus, individuals who were low in social anxiety symptoms were almost 9 times more likely to use blogs, while individuals who were high in social anxiety were more likely to use webcams. Data are presented in Table 9.

Predicting dating anxiety. Chi square tests were conducted to examine the whether demographic variables, relationship variables, or media use variables were related to social anxiety. A significant relation was found between DAQ group and the use of webcams in online communication, $\mathrm{X}^{2}(1)=3.849, p<.05$, as well as between DAS group and gender, $\mathrm{X}^{2}(1)=11.729, p<.01$. To examine the predictors of dating anxiety, binary logistic regression was conducted. First, demographic variables were entered as predictors of scores on each of the two measures of dating anxiety. Using the $25^{\text {th }}$ and $75^{\text {th }}$ percentiles on the DAQ, respondents were classified as having "high" and "low" dating anxiety. Approximately 59\% were correctly classified. The high DAQ group contained 181 participants, while the low DAQ group contained 174. The overall model was significant, $X^{2}(4)=18.714, p<.001$. Unique predictors were gender $(\beta=-$ $.764, \mathrm{Wald}=9.968, \mathrm{OR}=.466,95 \% \mathrm{Cl}=.290-.748, p<.01)$ and race $(\beta=.485$, Wald $=$ 
$5.880, \mathrm{OR}=1.625,95 \% \mathrm{Cl}=1.098-2.406, p<.05)$. Thus, female and minority respondents were more likely to have higher dating anxiety scores on the DAQ.

Second, making an online relationship was entered as a predictor of dating anxiety status. Approximately $54 \%$ were correctly classified, with 181 participants in the high group and 174 participants in the low group. The overall model was not significant, $X^{2}(1)=2.85, p>.05$. Making an online relationship was not a unique predictor of dating anxiety status on the $\mathrm{DAQ}$.

Third, media use variables were entered as predictors of dating anxiety on the DAQ. Fifty-one percent were correctly classified, with 181 participants in the high group and 174 participants in the low group. The overall model was significant, $X^{2}(8)=15.791$, $p<.05$. Webcam use was a unique predictor $(\beta=2.595$, Wald $=4.841, \mathrm{OR}=13.400$, $95 \% \mathrm{Cl}=1.328-135.230, p<.05)$; individuals who were high in dating anxiety on the DAQ were 13 times more likely to use webcams to maintain online relationships. Data presented in Table 10.

Using the $25^{\text {th }}$ and $75^{\text {th }}$ percentiles on the Dating Anxiety Survey, respondents were classified as "high" and "low" dating anxiety. Demographic variables were entered as predictors of DAS score, and the overall model was significant, $X^{2}(4)=13.495, p<$ .01 . Approximately $59 \%$ were correctly classified, with 179 participants in the high group and 167 in the low group. Gender was a unique predictor, with females more likely to have higher dating anxiety scores on the DAS $(\beta=-.879$, Wald $=11.986, \mathrm{OR}=.415$, $95 \% \mathrm{Cl}=.252-.683, p<.001)$.

Second, making an online relationship was entered as a predictor of dating anxiety status. Approximately $53 \%$ of participants were correctly classified, with 179 
participants in the high dating anxiety group and 167 in the low group. The overall model was not significant, $X^{2}(1)=2.88, p>.05$. Making an online relationship was not a unique predictor of dating anxiety status on the DAS.

Finally, media use variables were then entered as predictors of dating anxiety on the DAS. Approximately $54 \%$ were correctly classified, with 179 participants in the high dating anxiety group and 167 in the low group. The overall model was not significant, $\mathrm{X}^{2}$ $(8)=4.998, p>.10$. Data are presented in Table 11.

Predicting Internet use. To examine predictors of Internet use, binary logistic regression was conducted. Scores on the SPAI, DAS, and DAQ were entered as predictors of whether the participant had used email, chat rooms, IM, blogs, webcams, or online dating services to maintain the online relationship. None of the overall models were significant. Data are presented in Table 12.

Predicting relationship status. To examine predictors of relationship status, binary logistic regression was conducted. Scores on the SPAI, DAS, and DAQ were entered as predictors of whether the participant had ever been on a date. The overall model was significant $X^{2}(3)=14.663, p<.01$. Approximately $99 \%$ were correctly classified. Results indicated that individuals who were low on the DAQ (indicating higher levels of dating anxiety) were less likely to report ever having gone on a date, $\beta=-.367$, Wald $=$ $11.481, \mathrm{OR}=.693,95 \% \mathrm{Cl}=.561-.857, \mathrm{p}<.001$. Additionally, the SPAI, DAS and DAQ were entered as predictors of whether the participant had been on a date in the last 6 months. The overall model was significant, $X^{2}(3)=48.71, p<.001$. Approximately $90 \%$ were correctly classified. Results indicated that individuals who were low on the DAQ were less likely to report going on a date in the last 6 months, $\beta=-.204$, Wald $=30.484$, 
$\mathrm{OR}=.815,95 \% \mathrm{Cl}=.758-.877, p<.001$. Finally, the SPAI, DAS and DAQ were entered as predictors of whether a face to face meeting had taken place with the online relationship partner. The overall model was not significant, $X^{2}(3)=3.161, p>.10$. Data are presented in Table 13.

\section{Discussion}

This investigation into the use of the Internet by college students partially replicated and extended previous research. Results were similar to those of Donn and Sherman (2002), Knox et al. (2001), and Ward and Tracey (2004), with college students reporting using the Internet as a means to establish and maintain romantic and platonic relationships. This was one of the first studies to examine the association between social and dating anxiety and Internet use, as well as examine specific media that may be likely to be utilized in the development and retention of online relationships.

\section{Social Anxiety}

The majority of findings with respect to social anxiety severity were inconsistent with the hypotheses that individuals higher in social anxiety symptoms would report more use of the Internet and certain media to make and maintain relationships. Although individuals low in social anxiety reported using blogs significantly more than individuals who were high in social anxiety, use of webcams in relationship maintenance was almost 9 times more likely for those high in social anxiety. This may be due to an association between social anxiety and increased computer ability and interest, or be a result of the Internet acting as an intermediary between two individuals. Although communicating partners can see each other, there is a buffer of cyberspace between them and certain physiological characteristics (such as trembling or blushing) may not 
be as easily noted. Given that the majority of the sample reported using both email and IM daily, it is not surprising that there were no differences with respect to social anxiety. Social anxiety symptoms were not found to be predictive of media use or relationship variables.

Dating Anxiety

Women and minorities were more likely to endorse symptoms of dating anxiety. Women may feel more pressure to be involved in a relationship than men. Sociobiological theory states that, since women can only have a limited number of offspring at one time, it is vital to couple with a partner that can provide stability and security for any offspring. Men, however, can have multiple partners and offspring, and are more likely to remain uncoupled longer (Gould, 1987). However, the racial difference may be a function of the location as the racial make-up of West Virginia University is such that minorities may have difficulty establishing dating relationships given the smaller amount of ethnic diversity on campus.

Again, the majority of findings regarding dating anxiety were inconsistent with the hypotheses. Individuals high in dating anxiety symptoms, as assessed by the Dating and Assertion Questionnaire, were 13 times more likely to endorse using webcams to maintain relationships. This, again, may be due to the Internet acting as a buffer.

\section{Summary}

The results of the current study extended previous literature, but were inconsistent with previous literature. Individuals who reported high levels of social and/or dating anxiety were not more likely to use the Internet to make online relationships than those who reported lower levels of social or dating anxiety. However, 
the current investigation extended the literature by demonstrating that certain online media were more likely to be used by individuals reporting social and dating anxiety symptoms, particularly the use of web cameras. This was one of the first investigations to examine the association between particular online media and scores on established measures of social and dating anxiety.

\section{Limitations and Future Directions}

Limitations of this study should be noted. First, a university sample was used, which may have influenced not only the level of Internet use but also the level of technological ability. Future research may benefit from using a larger community sample, which contains a larger array of ages, backgrounds, and ability levels. A crosssectional community sample may provide information on a larger range of ability, and thus be more ecologically valid. Second, the sample primarily consisted of EuropeanAmerican individuals. Although representative of the racial make-up of both West Virginia University and the state of West Virginia, future studies may benefit from inclusion of individuals from other ethnicities and racial backgrounds, as well as urban areas, to determine whether differences in computer use and dating exist. It is important to note, however, that the sample did include a range of individuals with significant symptoms of social anxiety disorder.

Additionally, the proportion of relationships made online to relationships in general was not clearly established. By understanding the base number of relationships a participant has versus the proportion of relationships made online, further analysis of level of social activity could be better understood. If a given participant stated that she/he had made three relationships online, and stated that they had 4 friends/romantic 
partners total, it would be a valuable piece of information as to the participant's level of social activity.

Implications

The current investigation has several implications for intervention and identification of social and dating anxiety, as well as for dating relationships in general. The internet can be a vital tool for individuals living in areas where their particular racial/ethnic group, religion, or sexual orientation is not well represented. For individuals in remote or culturally homogenous areas, the Internet and online media can provide a link to similar others. Results suggest that individuals with social and/or dating anxiety are more likely to use the certain online media (i.e., web cameras) to make and maintain relationships. Given this finding, clinicians may want to consider using the Internet and certain online media as therapeutic tools for clients in need of exposure to social or relational situations. Clients presenting with social and/or dating anxiety can be assessed as to their level of computer and media knowledge, experience, and use, and then given access to controlled webcams or chat rooms in which they can practice skills and interpersonal tasks. By using online media as a low to mid-level step in an exposure hierarchy, clinicians may have another potential environment for clients to practice at home the skills they learn in therapy sessions. Furthermore, the Internet may be an ideal forum for discussions about social/dating anxiety symptoms and treatment, or even a potential outlet for group therapy. Individuals in group therapy may find it helpful to have online forums on which they can discuss coping skills, practice methods, and provide support to others. Though the ultimate goal remains having successful and appropriate live social interactions, clients who are starting from an extremely low 
baseline may be served well by increasing any social interaction, live or in cyberspace. 


\section{References}

American Psychiatric Association. (2000). Diagnostic and statistical manual of mental disorders ( $4^{\text {th }}$ ed., text revision). Washington, DC.

Anderson, C. A., \& Arnoult, L. H. (1985). Attributional style and everyday problems in living: Depression, loneliness, and shyness. Social Cognition, 3, 16-35.

Beidel, D. C., Turner, S. M., Stanley, M. A., \& Dancu, C. V. (1989). The social phobia and anxiety inventory: Concurrent and external validity. Behavior Therapy, 20, 417-427.

Berzonsky, M. D., \& Kuk, L. S. (2000). Identity status, identity processing style, and the transition to university. Journal of Adolescent Research, 15, 81-98.

Booth, R. (2000). Loneliness as a component of psychiatric disorders. Medscape Mental Health, 5. Retrieved December 17, 2005, from http://www.medscape.com/Medscape/psychiatry/journal/2000/v05.n02/mh3272.b oot/mh3272.boot-01.html.

Calsyn, R. J., Winter, J. P., \& Burger, G. K. (2005). The relationship between social anxiety and social support in adolescents: A test of competing causal models. Adolescence, 40, 103-113.

Calvert, J. D., Moore, D., \& Jensen, B. J. (1987). Psychometric evaluation of the dating anxiety survey: A self-report questionnaire for the assessment of dating anxiety in males and females. Journal of Psychopathology and Behavioral Assessment, 9, 341-350. 
Chen, Y., \& Persson, A. (2002). Internet use among young and older adults: Relation to psychological well-being. Educational Gerontology, 28, 731-745.

Davidson, J. R. T., Potts, N. L., Richichi, E. A., Ford, S. M., Krishnan, K. R., Smith, R. D., \& Wilson, W. (1991). The brief social phobia scale. Journal of Clinical Psychiatry, 52, 48-51.

Davila, J., \& Beck, J. G. (2002). Is social anxiety associated with impairment in close relationships? A preliminary investigation. Behavior Therapy, 33, 427-446.

Donn, J. E., \& Sherman, R. C. (2002). Attitudes and practices regarding the formation of romantic relationships on the internet. CyberPsychology and Behavior, 5, 107123.

Erwin, B. A., Turk, C. L., Heimberg, R. G., Fresco, D. M., \& Hantula, D. A. (2004). The internet: home to a severe population of individuals with social anxiety disorder? Journal of Anxiety Disorders, 18, 629-646.

Gould, S. J. (1987). An urchin in the storm: Essays about books and ideas. N.Y.: W. W. Norton.

Himadi, W. G., Arkowitz, H., Hinton, R., \& Perl, J. (1980). Minimal dating and its relationship to other social problems and general adjustment. Behavior Therapy, $11,345-352$.

Hope, D. A., \& Heimberg, R. G. (1990). Dating anxiety. In H. Leitenberg (Ed.), Handbook of social and evaluation anxiety. New York: Plenum Press.

Internet World Statistics. (2005). Internet usage statistics - The big picture. Retrieved on March 15, 2005 from http://internetworldstats.com/stats.htm 
Jones, W. H., Cavert, C. W., Snider, R. L., \& Bruce, T. (1985). Relational stress: An analysis of situations and events associated with loneliness. In S. Duck \& D. Perlman (Eds.), Understanding personal relationships (pp. 221-242). London: Sage.

Knox, D., Daniels, V., Sturdivant, L., \& Zusman, M. E. (2001). College student use of the internet for mate selection. College Student Journal, 35, 158-160.

Kraut, R., Patterson, M., Lundmarkm, V., Kiesler, S., Mukopadhyay, T., \& Scherlis, W. (1998). Internet paradox: A social technology that reduces social involvement and psychological well-being? American Psychologist, 53, 1017-1031.

Kraut, R., Kiesler, S., Boneva, B., Cummings, J., Helgeson, V., \& Crawford, A. (2002). Internet paradox revisited. Journal of Social Issues, 58, 49-74.

Largo-Wight, E., Peterson, P. M., \& Chen, W. W. (2005). Perceived problem solving, stress, and health among college students. American Journal of Health Behavior, 29, 360-370.

Levenson, R. W., \& Gottman, J. (1978). Toward the assessment of social competence. Journal of Consulting and Clinical Psychology, 46, 453-462.

Mallinckrodt, B., \& Wei, M. (2005). Attachment, social competencies, social support, and psychological distress. Journal of Counseling Psychology, 52, 358-367.

McKenna, K. Y. (1999). The computers that bind: Relationship formation on the internet. Unpublished doctoral dissertation. Ohio University.

McKenna, K. Y., Green, A. S., \& Gleason, M. E. (2002). Relationship formation on the internet: What's the big attraction? Journal of Social Issues, 58, 9-31. 
Morahan-Martin, J., \& Schumacher, P. (2003). Loneliness and social uses of the Internet. Computers in Human Behavior, 19, 659-671.

Peters, L. (2000). Discriminant validity of the social phobia and anxiety inventory (SPAI), the social phobia scale (SPS) and the social interaction anxiety scale (SIAS). Behavior Research and Therapy, 38, 943-950.

The Pew Internet and American Life Project. (2005). Latest trends. Retrieved on March 15, 2005 from http://www.pewinternet.org/trends.asp\#/demographics.

Ponzetti , J. J. (1990). Loneliness among college students. Family Relations, 39, p336340.

Sullivan, B. (2002). Online dating: Everyone's doing it. Retrieved on March 15, 2005 from http://msnbc.msn.com/id/3078729.

Turner, S. M., Beidel, D. C., Dancu, C. V., \& Stanley, M. A. (1989). An empirically derived inventory to measure social fears and anxiety: The social phobia and anxiety inventory. Journal of Consulting and Clinical Psychology, 57, 35-40.

Ward C. C., \& Tracey, T. J. G. (2004). Relation of shyness with aspects of online relationship involvement. Journal of Social and Personal Relationships, 21, 611623.

Wästlund, E., Norlander, T., \& Archer, T. (2001). Internet blues revisited: Replication and extension of an internet paradox study. CyberPsychology and Behavior, 4, 385-391.

Wilcox, P., Winn, S., \& Fyvie-Gauld, M. (2005). 'It was nothing to do with the university, it was just the people': The role of social support in the first-year experience of higher education. Studies in Higher Education, 30, 707-722. 
UCLA Internet Report - Year Three. (2002). Surveying the digital future. Retrieved on March 15, 2005 from http://ccp.ucla.edu/pdf/UCLA-Internet-Report-YearThree.pdf. 
Table 1.

Demographic Characteristics of the Full Sample and Male and Female Participants

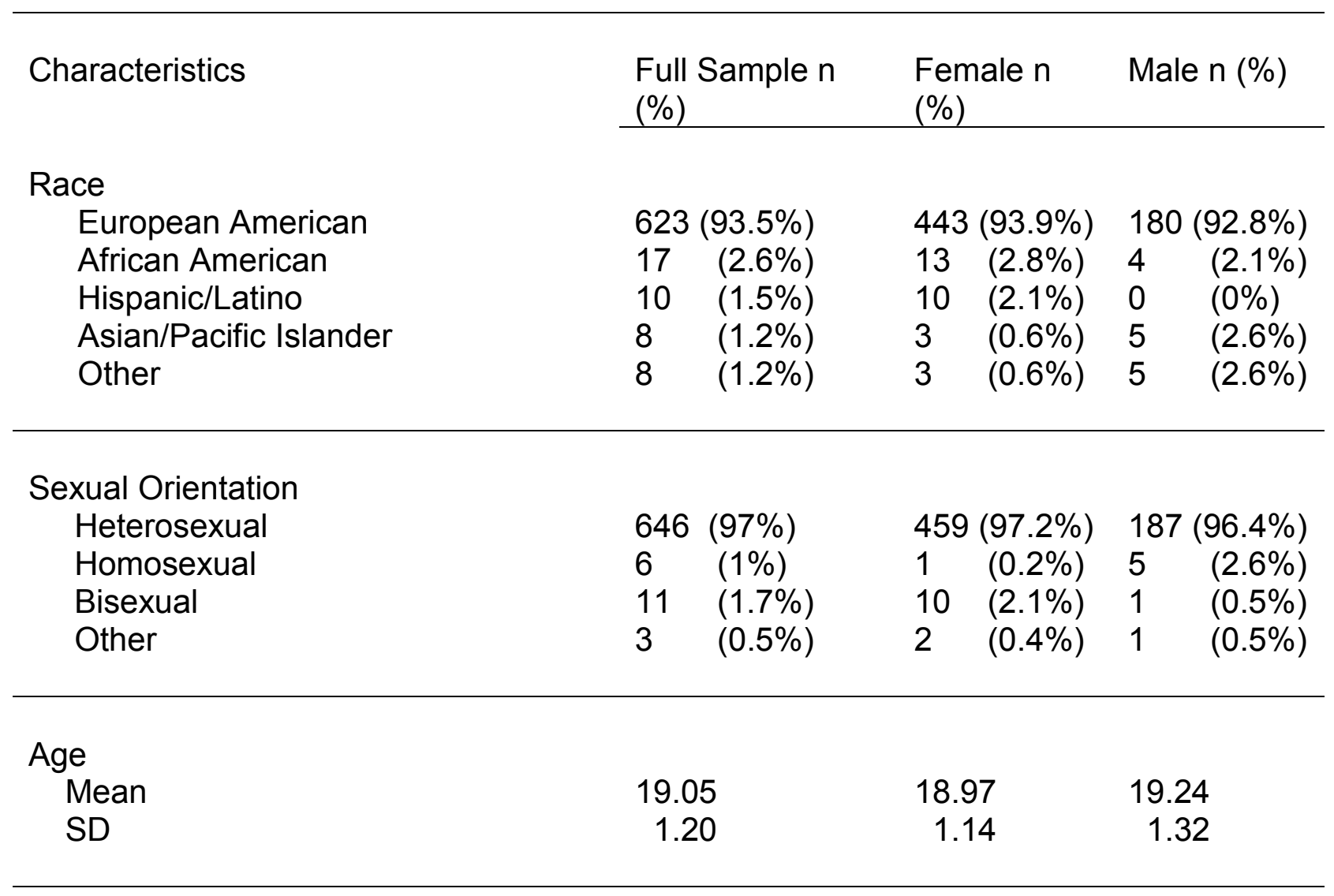


Table 2.

Computer Use Statistics of the Full Sample and Male and Female Participants

\begin{tabular}{|c|c|c|c|}
\hline Online Media & Full Sample n (\%) & Female n (\%) & Male n (\%) \\
\hline Chat Room & $520(78.1 \%)$ & $361(76.5 \%)$ & $159(82 \%)$ \\
\hline Instant Messaging & $663(99.5 \%)$ & $471(99.8 \%)$ & $192(99 \%)$ \\
\hline Web Log (BLOG) & $322(48.3 \%)$ & $231(48.9 \%)$ & $91(46.9 \%)$ \\
\hline Web Camera (Webcam) & $310(46.5 \%)$ & $191(40.5 \%)$ & $119(61.3 \%)$ \\
\hline Online Dating Service & $87 \quad(13.1 \%)$ & $53 \quad(11.2 \%)$ & $34(17.5 \%)$ \\
\hline
\end{tabular}




\section{Table 3.}

Intercorrelation Matrix of Demographic Variables Between High and Low Social Anxiety Groups

\begin{tabular}{lllllll}
\hline Variable & \multicolumn{2}{l}{$\begin{array}{l}\text { Sexual } \\
\text { Orientation }\end{array}$} & \multicolumn{3}{l}{ Race/Ethnicity } & \multicolumn{3}{l}{ Year in } \\
& \multicolumn{1}{l}{ School } \\
\cline { 2 - 7 } & High & Low & High & Low & High & Low \\
\cline { 2 - 7 } Gender & .00 & -.00 & .10 & .08 & -.02 & -.01 \\
Sexual & & & $.24^{* *}$ & .07 & -.10 & -.11 \\
Orientation & & & & & & \\
Race/Ethnicity & & & & .10 & -.05 \\
& & & & & & \\
\hline Note. ${ }^{* *} p<.01$
\end{tabular}


Table 4.

Intercorrelation Matrix of Computer Use Variables (Media used to maintain online relationship) Between High and Low Social Anxiety Groups

\begin{tabular}{|c|c|c|c|c|c|c|c|c|c|c|}
\hline \multirow[t]{3}{*}{ Variable } & \multicolumn{2}{|c|}{ Chat Rooms } & \multicolumn{2}{|l|}{ IM } & \multicolumn{2}{|l|}{ Blogs } & \multicolumn{2}{|c|}{ Webcams } & \multicolumn{2}{|c|}{ Dating Site } \\
\hline & High & Low & High & Low & High & Low & High & Low & High & Low \\
\hline & $.39^{* * a}$ & $.11^{a}$ & $.55^{\star * a}$ & $.47^{* * a}$ & $.20^{* *}$ & -.03 & $.19^{* * a}$ & $.39 * * a$ & .12 & $.19^{\star *}$ \\
\hline Email & & & & & & & & & & \\
\hline & & & $.24^{* *}$ & .11 & .07 & -.02 & $.24^{* *}$ & $.18^{*}$ & -.03 & -.02 \\
\hline Chat Rooms & & & & & & & & & & \\
\hline & & & & & $.24^{* *}$ & .10 & .12 & $.20^{*}$ & .03 & .10 \\
\hline IM & & & & & & & & & & \\
\hline Blogs & & & & & & & $.20 * * a$ & $-.01^{a}$ & -.04 & -.01 \\
\hline Webcams & & & & & & & & & ${ }^{-} .02^{a}$ & $.50 * * a$ \\
\hline
\end{tabular}

Note. ${ }^{* *} p<.01,{ }^{*} p<.05 ;{ }^{a}=$ statistically significant difference between high and low groups 
Table 5.

Intercorrelation Matrix of Relationship Variables and Social/Dating Anxiety Measures Between High and Low Social Anxiety Groups

\begin{tabular}{|c|c|c|c|c|c|c|c|c|c|c|c|c|}
\hline \multirow[t]{2}{*}{ Variable } & \multicolumn{2}{|c|}{$\begin{array}{l}\text { Been on a date } \\
\text { in last } 6 \text { months }\end{array}$} & \multicolumn{2}{|c|}{$\begin{array}{l}\text { Have } \\
\text { significant } \\
\text { other }\end{array}$} & \multicolumn{2}{|c|}{ SPAI score } & \multicolumn{2}{|c|}{ DAS score } & \multicolumn{2}{|c|}{ DAQ score } & \multicolumn{2}{|c|}{$\begin{array}{l}\text { Made } \\
\text { online } \\
\text { relationship }\end{array}$} \\
\hline & High & Low & High & $\begin{array}{l}\text { Lo } \\
\text { w }\end{array}$ & High & Low & High & Low & High & Low & High & Low \\
\hline $\begin{array}{l}\text { Ever } \\
\text { been on } \\
\text { a date }\end{array}$ & $.36^{* * a}$ & $-.02^{a}$ & .10 & -.06 & -.40 & .06 & -.41 & .10 & $-.21^{* * a}$ & -.07 & .03 & .05 \\
\hline $\begin{array}{l}\text { Been on } \\
\text { date in } \\
\text { last } 6 \\
\text { months }\end{array}$ & & & $.35^{\star * a}$ & $.13^{\mathrm{a}}$ & $.15^{* *}$ & .07 & .05 & .00 & $-.38^{\star * a}$ & $\begin{array}{l}-.01 \\
a\end{array}$ & -.04 & .13 \\
\hline $\begin{array}{l}\text { Have } \\
\text { signif. } \\
\text { other }\end{array}$ & & & & & .01 & -.10 & .07 & -.03 & -.08 & -.00 & -.12 & -.05 \\
\hline $\begin{array}{l}\text { SPAI } \\
\text { score }\end{array}$ & & & & & & & $.31^{* * a}$ & $.06^{a}$ & $-.20^{* \star a}$ & $.35^{* *}$ & -.04 & .07 \\
\hline $\begin{array}{l}\text { DAS } \\
\text { score }\end{array}$ & & & & & & & & & -.15 & $-20^{* *}$ & $.01^{\mathrm{a}}$ & $e^{-} .24^{* *}$ \\
\hline $\begin{array}{l}\text { DAQ } \\
\text { score }\end{array}$ & & & & & & & & & & & .05 & -.00 \\
\hline
\end{tabular}


Table 6.

Intercorrelation Matrix of Demographic Variables and Computer Use Variables (Media used to maintain online relationship) Between High and Low Social Anxiety Groups

\begin{tabular}{|c|c|c|c|c|c|c|c|c|}
\hline Variable & Genc & & Sext & ientation & Race & thnicity & Year i & School \\
\hline & High & Low & High & Low & High & Low & High & Low \\
\hline Email & -.00 & -.11 & .01 & -.08 & -.01 & .03 & -.02 & .14 \\
\hline Chat Rooms & .07 & .05 & .03 & -.12 & -.07 & .05 & -.08 & .05 \\
\hline IM & -.11 & .10 & -.00 & -.07 & .01 & .04 & -.07 & $.19^{*}$ \\
\hline Blogs & -.08 & .05 & .04 & .02 & -.08 & .02 & .02 & -.03 \\
\hline Webcams & -.05 & -.08 & .02 & $-.16^{\star *}$ & .02 & -.12 & -.01 & .09 \\
\hline Dating Sites & .11 & .05 & $.03^{a}$ & $-.37^{* * a}$ & .04 & -.29 & $-.21^{* *}$ & -.03 \\
\hline
\end{tabular}

Note. ${ }^{* *} p<.01,{ }^{*} p<.05 ;{ }^{a}=$ statistically significant difference between high and low groups 
Table 7.

Intercorrelation Matrix of Relationship Variables, Social/Dating Anxiety Measures, and Demographic Variables Between High and Low Social Anxiety Groups

\begin{tabular}{|c|c|c|c|c|c|c|c|c|}
\hline Variable & Genc & & $\begin{array}{l}\text { Sexu } \\
\text { Orier }\end{array}$ & tion & Race & thnicity & Year & school \\
\hline & High & Low & High & Low & High & Low & High & Low \\
\hline $\begin{array}{l}\text { Ever been } \\
\text { on a date }\end{array}$ & -.01 & -.05 & -.02 & -.02 & .02 & -.02 & -.06 & .03 \\
\hline $\begin{array}{l}\text { Been on } \\
\text { date in last } \\
6 \text { months }\end{array}$ & .03 & .10 & .05 & $.17^{*}$ & .04 & .08 & -.02 & -.01 \\
\hline $\begin{array}{l}\text { Have } \\
\text { significant } \\
\text { other }\end{array}$ & $.16^{*}$ & .08 & .00 & -.08 & .07 & -.09 & -.12 & .05 \\
\hline $\begin{array}{l}\text { Made } \\
\text { online } \\
\text { relationship }\end{array}$ & -.08 & .12 & -.10 & -.12 & -.07 & -.06 & -.08 & .11 \\
\hline SPAI score & -.03 & 15 & .03 & -.03 & $.21^{* *}$ & .06 & .04 & .06 \\
\hline DAS score & $-.16^{*}$ & -.08 & -.10 & .02 & -.10 & .01 & .02 & .05 \\
\hline DAQ score & $.17^{*}$ & .06 & -.02 & .05 & -.07 & .00 & .01 & .06 \\
\hline
\end{tabular}

Note. ${ }^{* *} p<.01,{ }^{*} p<.05$ 
Table 8.

Intercorrelation Matrix of Relationship Variables, Social/Dating Anxiety Measures, and Computer Use Variables (Media used to maintain online relationship)

\begin{tabular}{|c|c|c|c|c|c|c|c|c|c|c|c|c|}
\hline \multirow[t]{2}{*}{ Variable } & \multicolumn{2}{|l|}{ Email } & \multicolumn{2}{|c|}{$\begin{array}{l}\text { Chat } \\
\text { Rooms }\end{array}$} & \multicolumn{2}{|l|}{ IM } & \multicolumn{2}{|l|}{ Blogs } & \multicolumn{2}{|c|}{ Webcams } & \multicolumn{2}{|c|}{ Dating Sites } \\
\hline & High & Low & High & Low & High & Low & High & Low & High & Low & High & Low \\
\hline $\begin{array}{l}\text { Ever been } \\
\text { on a date }\end{array}$ & -.02 & .03 & .03 & .02 & .04 & .07 & .03 & .01 & .01 & .01 & .02 & .01 \\
\hline $\begin{array}{l}\text { Been on } \\
\text { date in last } \\
6 \text { months }\end{array}$ & -.01 & .08 & -.07 & .04 & .01 & $.16^{*}$ & .03 & .02 & .04 & .03 & .07 & .02 \\
\hline $\begin{array}{l}\text { Have } \\
\text { significant } \\
\text { other }\end{array}$ & .05 & -.11 & -.04 & .08 & -.08 & -.15 & .02 & .06 & .08 & .03 & -.09 & .06 \\
\hline $\begin{array}{l}\text { Made } \\
\text { online } \\
\text { relationship }\end{array}$ & $.41^{* *}$ & $.28^{* *}$ & $.27^{* *}$ & $.23^{* *}$ & $.64^{* *}$ & $.71^{* *}$ & $.23^{* *}$ & .12 & .14 & .07 & $.24^{* *}$ & .12 \\
\hline SPAI score & -.08 & .08 & -.11 & -.09 & .02 & .15 & .05 & $.17^{*}$ & .00 & .03 & .05 & -.06 \\
\hline DAS score & -.04 & .00 & -.06 & -.09 & $.09^{a}$ & $-17^{\star a}$ & -.03 & .12 & -.08 & -.01 & -.01 & -.03 \\
\hline DAQ score & .03 & -.04 & .04 & .07 & -.08 & -.08 & -.01 & $-.17^{*}$ & $-15^{*}$ & -.06 & .02 & -.02 \\
\hline
\end{tabular}

Note. ${ }^{* *} p<.01,{ }^{*} p<.05 ;{ }^{\mathrm{a}}=$ statistically significant difference between high and low groups 
Table 9.

Logistic Regression Results for SPAI score as Dependent Variable

\begin{tabular}{|c|c|c|c|c|}
\hline Predictor & $\beta$ & Wald & $p$ & OR \\
\hline \multicolumn{5}{|l|}{ Group 1: $X^{2}(4)=4.432$} \\
\hline Gender & .08 & 12 & .73 & 1.09 \\
\hline Race & .10 & .25 & .62 & 1.10 \\
\hline Sexual Orientation & -.17 & .73 & .39 & .90 \\
\hline Year in School & .21 & 2.90 & .09 & 1.23 \\
\hline \multicolumn{5}{|l|}{ Group 2: $X^{2}(1)=.488$} \\
\hline $\begin{array}{l}\text { Made Online } \\
\text { Relationship }\end{array}$ & -.18 & .49 & .49 & .83 \\
\hline \multicolumn{5}{|l|}{ Group 2: $X^{2}(8)=20.043^{*}$} \\
\hline Email & -.70 & 3.55 & .06 & .50 \\
\hline Chat Room & .12 & .04 & .85 & 1.12 \\
\hline IM & .62 & 3.63 & .06 & 1.84 \\
\hline Blog & -2.39 & 4.63 & $.03^{*}$ & .09 \\
\hline Webcam & 2.18 & 4.07 & $.04^{*}$ & 8.85 \\
\hline $\begin{array}{l}\text { Online Dating } \\
\text { Service }\end{array}$ & -1.52 & 1.46 & .23 & .22 \\
\hline Telephone & -.56 & 2.52 & .11 & .57 \\
\hline Letter (Snail Mail) & .11 & .04 & .84 & 1.12 \\
\hline
\end{tabular}

Note. ${ }^{*} p<.05 ;$ SPAI $=$ Social Phobia and Anxiety Inventory. 
Table 10.

Logistic Regression Results for DAQ score as Dependent Variable

\begin{tabular}{|c|c|c|c|c|}
\hline Predictor & $\beta$ & Wald & $p$ & OR \\
\hline \multicolumn{5}{|l|}{ Group 1: $X^{2}(4)=18.71^{* * *}$} \\
\hline \multicolumn{5}{|l|}{ Demographics } \\
\hline Gender & -.76 & 9.97 & $.00^{\star * \star}$ & .47 \\
\hline Race & .49 & 5.88 & $.02^{*}$ & 1.63 \\
\hline Sexual Orientation & -.20 & .93 & .34 & .82 \\
\hline Year in School & -.18 & 1.95 & .16 & .84 \\
\hline \multicolumn{5}{|l|}{ Group 2: $X^{2}(1)=2.85$} \\
\hline Made Online & -.406 & 2.83 & .09 & .67 \\
\hline \multicolumn{5}{|l|}{ Relationship } \\
\hline \multicolumn{5}{|l|}{ Group 3: $X^{2}(8)=15.79$} \\
\hline \multicolumn{5}{|l|}{ Maintain relationship } \\
\hline Email & -.59 & 2.40 & .12 & .56 \\
\hline Chat Room & -1.25 & 3.07 & .08 & .29 \\
\hline IM & .24 & .58 & .45 & 1.27 \\
\hline Blog & -1.13 & 1.82 & .18 & .32 \\
\hline Webcam & 2.60 & 4.84 & $.03^{*}$ & 13.40 \\
\hline Online Dating Service & -1.02 & .96 & .33 & .36 \\
\hline Telephone & .15 & .17 & .68 & 1.16 \\
\hline Letter (Snail Mail) & .03 & .00 & .96 & 1.03 \\
\hline
\end{tabular}

Note. ${ }^{* * *} p<.0001,{ }^{* *} p<.01,{ }^{*} p<.05 ; \mathrm{DAQ}=$ Dating and Assertion Questionnaire. 
Table 11.

Logistic Regression Results for DAS score as Dependent Variable

\begin{tabular}{|c|c|c|c|c|}
\hline Predictor & $\beta$ & Wald & $p$ & OR \\
\hline \multicolumn{5}{|l|}{ Group 1: $X^{2}(4)=13.50^{* *}$} \\
\hline \multicolumn{5}{|l|}{ Demographics } \\
\hline Gender & -.88 & 11.99 & $.00^{* * *}$ & .42 \\
\hline Race & -.31 & 1.16 & .28 & .74 \\
\hline Sexual Orientation & .05 & .19 & .67 & 1.06 \\
\hline Year in School & .09 & .18 & .67 & 1.09 \\
\hline \multicolumn{5}{|l|}{ Group 2: $X^{2}(1)=2.88$} \\
\hline $\begin{array}{l}\text { Made Online } \\
\text { Relationship }\end{array}$ & -.42 & 2.84 & .09 & .66 \\
\hline \multicolumn{5}{|l|}{ Group 3: $X^{2}(8)=5.00$} \\
\hline \multicolumn{5}{|l|}{ Maintain relationship } \\
\hline Email & -.11 & .10 & .75 & .89 \\
\hline Chat Room & -.72 & 1.16 & .28 & .49 \\
\hline IM & .21 & .45 & .50 & 1.23 \\
\hline Blog & -1.64 & 2.17 & .14 & .19 \\
\hline Webcam & .13 & .02 & .90 & 1.14 \\
\hline $\begin{array}{l}\text { Online Dating } \\
\text { Service }\end{array}$ & -.62 & .24 & .62 & .54 \\
\hline Telephone & -.11 & .11 & .74 & .89 \\
\hline Letter (Snail Mail) & .27 & .25 & .62 & 1.31 \\
\hline
\end{tabular}

Note. ${ }^{* *} p<.01,{ }^{* * *} p<.001 ;$ DAS = Dating Anxiety Survey. 
Table 12.

Logistic Regression Results for Online Media as Dependent Variables

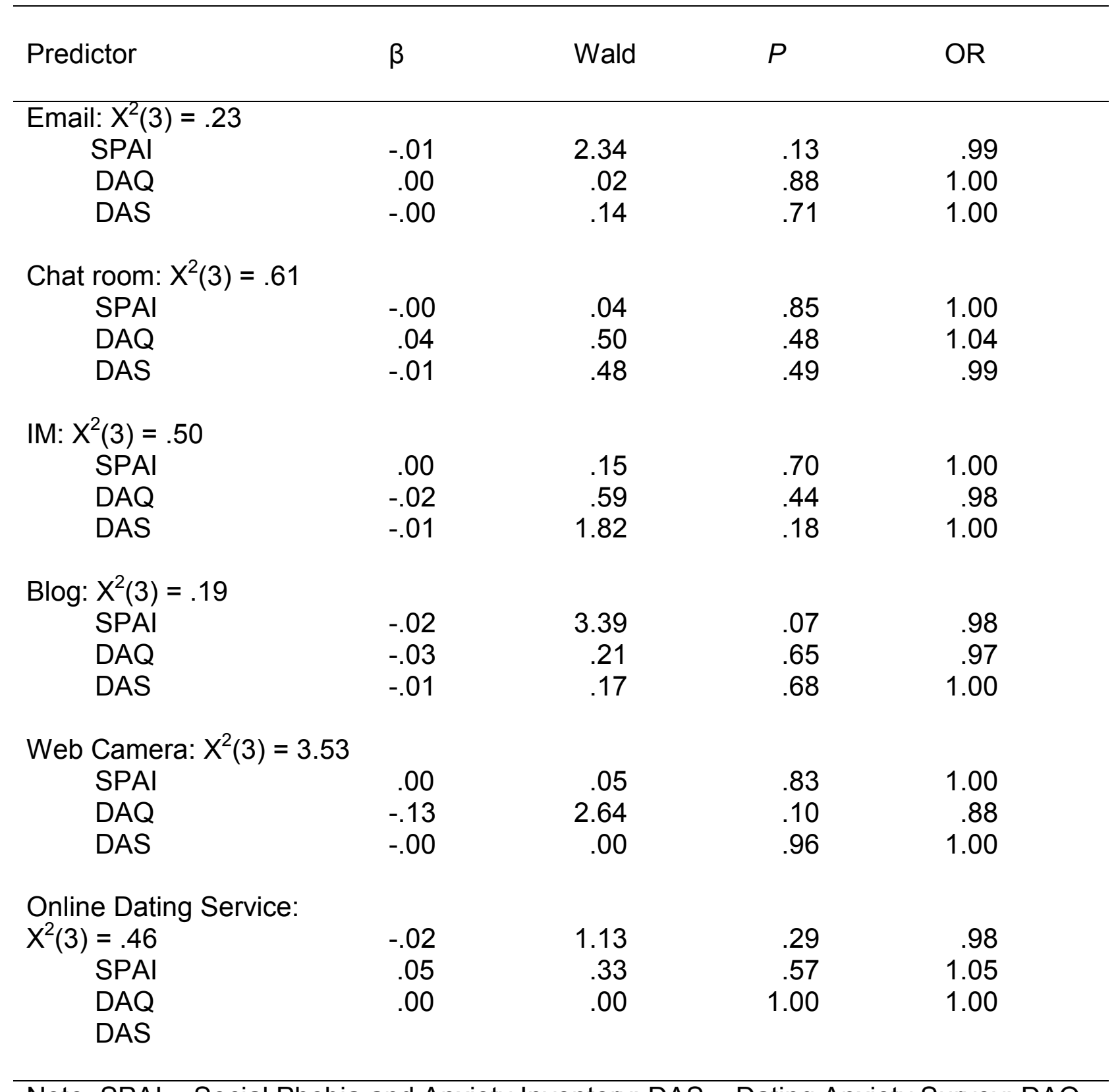

Note. SPAI = Social Phobia and Anxiety Inventory; DAS = Dating Anxiety Survey; DAQ = Dating and Assertion Questionnaire. 
Table 13.

Logistic Regression Results for Relationship Status as Dependent Variables

\begin{tabular}{|c|c|c|c|c|}
\hline Predictor & $\beta$ & Wald & $p$ & OR \\
\hline \multicolumn{5}{|c|}{$\begin{array}{l}\text { Ever been on a date: } \\
X^{2}(3)=14.66^{*}\end{array}$} \\
\hline SPAI & -.02 & .72 & .40 & .98 \\
\hline DAQ & -.37 & 11.48 & $.00^{* * *}$ & .69 \\
\hline DAS & .02 & .69 & .41 & 1.02 \\
\hline \multicolumn{5}{|c|}{$\begin{array}{l}\text { Date in last } 6 \text { months: } \\
X^{2}(3)=48.71^{* * *}\end{array}$} \\
\hline SPAI & .01 & .60 & .44 & 1.01 \\
\hline DAQ & -.20 & 30.48 & $.00^{* * *}$ & .82 \\
\hline DAS & .00 & .00 & .99 & 1.00 \\
\hline \multicolumn{5}{|c|}{$\begin{array}{l}\text { Face-to-face meeting: } \\
X^{2}(3)=3.16\end{array}$} \\
\hline SPAI & -.03 & 1.58 & .21 & .97 \\
\hline DAQ & -.00 & .69 & .41 & 1.00 \\
\hline DAS & -.00 & 1.70 & .30 & 1.00 \\
\hline
\end{tabular}

Note. ${ }^{*} p<.05,{ }^{* * *} p<.001 ;$ SPAI $=$ Social Phobia and Anxiety Inventory; DAS = Dating Anxiety Survey; DAQ = Dating and Assertion Questionnaire. 
Table 14.

Summary of Findings

$\underline{\text { Hypotheses }}$

Findings

Dating Practices

Low-Anxiety > High Social/Dating Anxiety

Use of Internet to Make/Maintain

Relationships

High Social/Dating Anxiety > Low Anxiety

Type of Media Used

Less personal (Email, Chat, IM):

High Social/Dating Anxiety > Low Anxiety

More Personal (Blog, Webcam, Dating Site):

High Social/Dating Anxiety < Low Anxiety

Face-to-Face Meeting

High Social/Dating Anxiety < Low Anxiety
Dating Practices

Dating Anxiety (DAQ) less likely to have

ever been on a date $(p<.001)$ or to have been on a date in the last 6 months $(p<$ $.001)$.

Use of Internet to Make/Maintain

Relationships

No differences between groups

Type of Media Used

Social Anxiety $>$ Webcam

Social Anxiety $<$ Blog

Dating Anxiety > Webcam

Face-To-Face Meeting

No difference between groups or severity 
Appendix A

Demographic Questionnaire

\begin{tabular}{|c|c|c|c|c|c|c|}
\hline \multicolumn{7}{|c|}{ 1) Date Questionnaire Completed: (MM/DD/YR) } \\
\hline \multicolumn{3}{|c|}{ 2) Gender: } & \multicolumn{3}{|c|}{ Female } & Male \\
\hline \multicolumn{4}{|c|}{ 3) Date of Birth: (MM/DD/YR) } & \multicolumn{3}{|c|}{ 4) Age: } \\
\hline \multicolumn{7}{|c|}{ 5)Sexual Orientation: } \\
\hline \multicolumn{2}{|c|}{ Heterosexual } & \multicolumn{2}{|c|}{ Gay } & \multicolumn{2}{|r|}{ Lesbian } & Bi-Sexual \\
\hline \multicolumn{7}{|c|}{ 6) Year in School: } \\
\hline \multicolumn{2}{|c|}{ Freshman } & \multicolumn{2}{|c|}{ Sophomore } & \multicolumn{2}{|r|}{ Junior } & Senior \\
\hline \multicolumn{7}{|c|}{ 7) Race/Ethnicity: } \\
\hline White & \multicolumn{2}{|c|}{ African-American } & \multicolumn{2}{|c|}{ Hispanic/Latino } & $\begin{array}{l}\text { Asian/Pacific } \\
\text { Islander }\end{array}$ & Biracial/Other \\
\hline
\end{tabular}


Appendix B

Computer/Internet Use Questionnaire

Instructions: The following questions deal with your computer and Internet use. Read each question and choose the best answer or answers.

1) Do you own a computer?

2) Do you have Internet access?
Yes

Yes
No

No

3) How much time do you spend on the Internet daily?
Less than 1
1 to 3 hours
3 to 5 hours
5 to 7 hours
Greater than 7
hour
hours

4) How experienced are you with using the Internet?

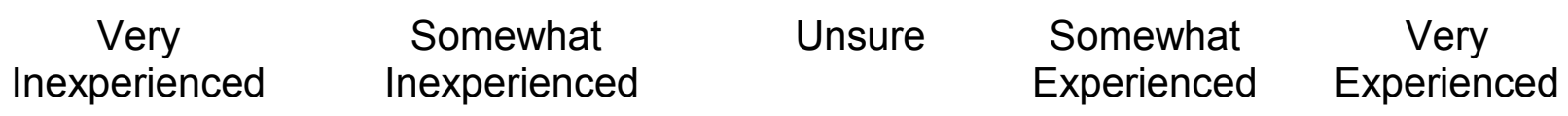

5) How comfortable/at ease are you with using the Internet?

\begin{tabular}{|c|c|c|c|}
\hline $\begin{array}{c}\text { Very } \\
\text { Uncomfortable }\end{array}$ & $\begin{array}{l}\text { Somewhat } \\
\text { Uncomfortable }\end{array}$ & Unsure & $\begin{array}{l}\text { Somewhat } \\
\text { Comfortable }\end{array}$ \\
\hline
\end{tabular}

6) Have you ever used electronic mail (e-mail)? $\quad$ Yes $\quad$ No

7) How often do you check, or send electronic mail (e-mail)?
Every three
Every month
Every week
Every day
Multiple times a day

8) How experienced are you with checking, sending or receiving e-mail?

\begin{tabular}{|c|c|c|c|}
\hline $\begin{array}{c}\text { Very } \\
\text { Inexperienced }\end{array}$ & $\begin{array}{l}\text { Somewhat } \\
\text { Inexperienced }\end{array}$ & Unsure & $\begin{array}{l}\text { Somewhat } \\
\text { Experienced }\end{array}$ \\
\hline
\end{tabular}

9) How comfortable/at ease are you with using e-mail?

\begin{tabular}{|c|c|c|c|}
\hline $\begin{array}{l}\text { Very } \\
\text { ncomfortable }\end{array}$ & $\begin{array}{l}\text { Somewhat } \\
\text { Uncomfortabl }\end{array}$ & Unsure & $\begin{array}{l}\text { Somewhat } \\
\text { Comfortable }\end{array}$ \\
\hline
\end{tabular}


10) Have you ever participated in a chat room?

Yes

No

11) How often do you participate in chat rooms?
Every three
Every month
Every week
Every day
Multiple times months

12) How experienced are you with chat room participation?

\begin{tabular}{|c|c|c|}
\hline $\begin{array}{c}\text { Very } \\
\text { Inexperienced }\end{array}$ & $\begin{array}{l}\text { Somewhat } \\
\text { Inexperienced }\end{array}$ & Unsure \\
\hline
\end{tabular}

13) How comfortable are you with chat room participation?

$\begin{array}{ccccc}\text { Very } & \text { Somewhat } & \text { Unsure } & \begin{array}{c}\text { Somewhat } \\ \text { Comfortable }\end{array} & \begin{array}{c}\text { Very } \\ \text { Comfortable }\end{array}\end{array}$

14) Have you ever used instant messaging (IM)? $\quad$ Yes $\quad$ No

15) How often do you use instant messaging (IM)?
Every three
Every month
Every week
Every day
Multiple times months
a day

16) How experienced are you with using instant messaging (IM)?

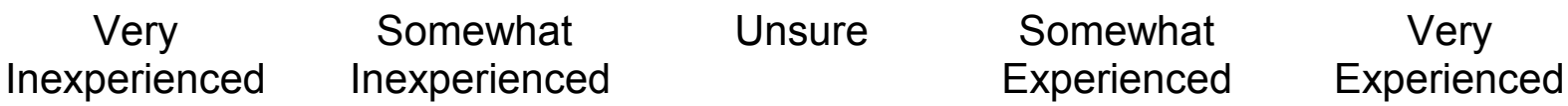

17) How comfortable are you with using instant messaging (IM)?

$\begin{array}{cc}\text { Very } & \text { Somewhat } \\ \text { Uncomfortable } & \text { Uncomfortable }\end{array}$

18) Have you ever created or read web logs (blogs)?
Unsure

Somewhat

Comfortable

Yes

19) How often do you create, update, or read web logs (blogs)?
Every three
Every month
Every week
Every day
Multiple times a day


20) How experienced are you with creating, updating or reading web logs (blogs)?

Very Somewhat Unsure Somewhat Very Inexperienced Inexperienced Experienced Experienced

21) How comfortable are you with creating, using, or reading web logs (blogs)?

$\begin{array}{ccccc}\begin{array}{c}\text { Very } \\ \text { Uncomfortable }\end{array} & \begin{array}{c}\text { Somewhat } \\ \text { Uncomfortable }\end{array} & \text { Unsure } & \begin{array}{c}\text { Somewhat } \\ \text { Comfortable }\end{array} & \begin{array}{c}\text { Very } \\ \text { Comfortable }\end{array}\end{array}$

22) Have you ever used or watched a web camera $\quad$ Yes No (web cam)?

23) How often do you use or watch web camera (web cam) broadcasts?

\begin{tabular}{|c|c|c|c|}
\hline $\begin{array}{l}\text { Every three } \\
\text { months }\end{array}$ & Every month & Every week & Every day \\
\hline
\end{tabular}

24) How experienced are you with using or watching web camera (web cam) broadcasts?

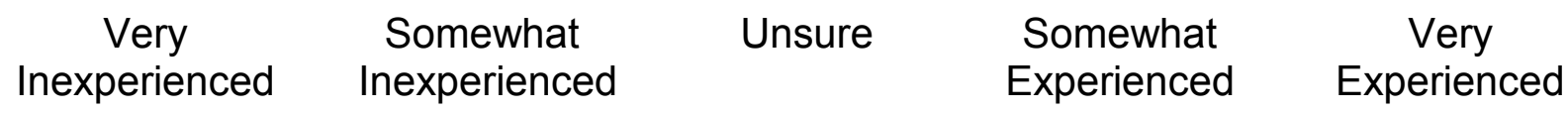

25) How comfortable are you using or watching web camera (web cam) broadcasts?

$\begin{array}{ccccc}\text { Very } & \text { Somewhat } & \text { Unsure } & \begin{array}{c}\text { Somewhat } \\ \text { Comfortable }\end{array} & \begin{array}{c}\text { Very } \\ \text { Comfortable }\end{array}\end{array}$

26) Have you ever read, made, or updated an ad on $\quad$ Yes $\quad$ No an online dating service (e.g., Match.com, Yahoo! Personals)

27) How often do you read, make, or responding to an ad on an online dating service?

\begin{tabular}{|c|c|c|c|}
\hline $\begin{array}{c}\text { Every three } \\
\text { months }\end{array}$ & Every month & Every week & Every day \\
\hline
\end{tabular}


28) How experienced are you with reading, making, or responding to an ad on an online dating service?
Very
Somewhat
Unsure
Somewhat
Experienced
Very
Inexperienced Inexperienced
Experienced

29) How comfortable are you with reading, making, or responding to an ad on an online dating service?

$\begin{array}{ccccc}\begin{array}{c}\text { Very } \\ \text { Uncomfortable }\end{array} & \begin{array}{c}\text { Somewhat } \\ \text { Uncomfortable }\end{array} & \text { Unsure } & \begin{array}{c}\text { Somewhat } \\ \text { Comfortable }\end{array} & \begin{array}{c}\text { Very } \\ \text { Comfortable }\end{array}\end{array}$

30) Have you ever made an online relationship

Yes

No (One in which you meet online before you meet face-to-face)?

31) How many online relationships have you made?

32) What was the ultimate goal of forming these online relationships?
Acquaintance
Friend
Close or Best
Romantic partner Friend

32) Of all the relationships you have formed online, what is the most common nature of the relationships?

$\begin{array}{llll}\text { Acquaintance } & \text { Friend } & \text { Close or Best Romantic partner }\end{array}$ Friend

33) Think of the closest online relationship you have made to date. What was the nature of this relationship?

Acquaintance Friend

34) Did a face-to-face meeting result from this online relationship?

Close or Best Romantic partner Friend Yes No

35) Compared to traditional face-to-face relationships, how quickly did the online relationship develop in terms of intimacy?

Slower than traditional

Same as traditional

Faster than traditional 
36) How did you meet the person with whom you have/had the closest online relationship?

Chat room Instant messaging Web Log Web Cam $\begin{gathered}\text { Online dating } \\ \text { service }\end{gathered}$

37) What online media did you use to maintain the closest relationship? (Circle all that apply)

\begin{tabular}{|c|c|c|c|c|}
\hline E-Mail & Chat rooms & IM & Blogs & Web Cams \\
\hline
\end{tabular}

38) What media was used most to maintain this relationship?

E-Mail Chat rooms IM Blogs Web Cams $\begin{gathered}\begin{array}{c}\text { Online } \\ \text { dating } \\ \text { services }\end{array} \\ \text { ser }\end{gathered}$

39) Did you speak to the person with whom you had an online relationship on the telephone?

40) Did you write letters (snail

No mail) to the person with whom

No you had/have an online relationship? 
Appendix C

Friendship and Dating Practices Questionnaire

Instructions: The following questions deal with your current dating and friendship practices. Read each question and choose the best answer or answers.

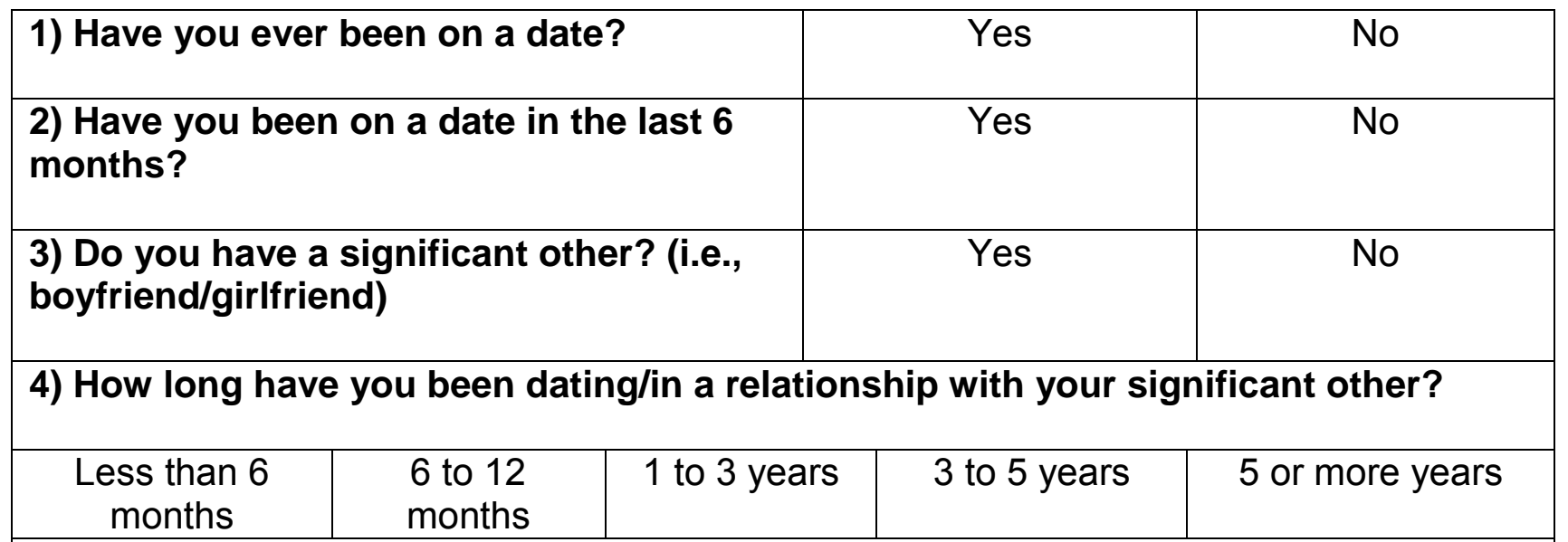

\section{5) How did you meet your significant other?}

\begin{tabular}{|c|c|c|c|c|}
\hline $\begin{array}{c}\text { In high school } \\
\text { class }\end{array}$ & $\begin{array}{c}\text { In college } \\
\text { class }\end{array}$ & $\begin{array}{c}\text { Introduced by } \\
\text { Mutual Friend }\end{array}$ & Met Online & Met at a bar/club \\
\hline $\begin{array}{c}\text { Were friends } \\
\text { before }\end{array}$ & $\begin{array}{c}\text { Part of the } \\
\text { same group }\end{array}$ & $\begin{array}{c}\text { Gym/Outdoor } \\
\text { activities }\end{array}$ & Club/Organization & Church/Synagogue \\
\hline W) & & & \\
\hline
\end{tabular}

6) What do you consider a "date"? (Circle all that apply)

\begin{tabular}{|c|c|c|c|c|}
\hline $\begin{array}{c}\text { One on one } \\
\text { outing (dinner, } \\
\text { movie, etc.) }\end{array}$ & $\begin{array}{c}\text { One on one } \\
\text { staying in } \\
\text { (rent video, } \\
\text { "hang out") }\end{array}$ & $\begin{array}{c}\text { Group outing } \\
\text { with significant } \\
\text { other and } \\
\text { family }\end{array}$ & $\begin{array}{c}\text { Group outing with } \\
\text { significant other } \\
\text { and friends }\end{array}$ & $\begin{array}{c}\text { Group outing with } \\
\text { significant other } \\
\text { and acquaintances }\end{array}$ \\
\hline 7) Whatenting
\end{tabular}

\section{7) What is the most common type of date you go on?}

\begin{tabular}{|c|c|c|c|c|}
\hline $\begin{array}{c}\text { One on one } \\
\text { outing (dinner, } \\
\text { movie, etc.) }\end{array}$ & $\begin{array}{c}\text { One on one } \\
\text { staying in } \\
\text { (rent video, } \\
\text { "hang out") }\end{array}$ & $\begin{array}{c}\text { Group outing } \\
\text { with significant } \\
\text { other and } \\
\text { family }\end{array}$ & $\begin{array}{c}\text { Group outing with } \\
\text { significant other } \\
\text { and friends }\end{array}$ & $\begin{array}{c}\text { Group outing with } \\
\text { significant other } \\
\text { and acquaintances }\end{array}$ \\
\hline
\end{tabular}

\section{8) When you have gone on a first date, what is the most common type of date?}

\begin{tabular}{|c|c|c|c|c|}
\hline $\begin{array}{c}\text { One on one } \\
\text { outing (dinner, } \\
\text { movie, etc.) }\end{array}$ & $\begin{array}{c}\text { One on one } \\
\text { staying in } \\
\text { (rent video, }\end{array}$ & $\begin{array}{c}\text { Group outing } \\
\text { with significant } \\
\text { other and }\end{array}$ & $\begin{array}{c}\text { Group outing with } \\
\text { significant other } \\
\text { and friends }\end{array}$ & $\begin{array}{c}\text { Group outing with } \\
\text { significant other } \\
\text { and acquaintances }\end{array}$ \\
\hline
\end{tabular}




\begin{tabular}{|l|c|c|c|}
\hline "hang out") & family & & \\
\hline 9) Do you have a best or closest friend? & Yes & No \\
\hline
\end{tabular}

10) How long have you known your best or closest friend?

\begin{tabular}{c|l|l|l|l}
$\begin{array}{c}\text { Less than } 6 \\
\text { months }\end{array}$ & $\begin{array}{c}6 \text { to } 12 \\
\text { months }\end{array}$ & 1 to 3 years & 3 to 5 years & 5 or more years \\
\hline
\end{tabular}

11) How did you meet your best or closest friend?

\begin{tabular}{|c|c|c|c|c|}
\hline $\begin{array}{c}\text { In high school } \\
\text { class }\end{array}$ & $\begin{array}{c}\text { In college } \\
\text { class }\end{array}$ & $\begin{array}{c}\text { Introduced by } \\
\text { Mutual Friend }\end{array}$ & Met Online & Met at a bar/club \\
\hline $\begin{array}{c}\text { Parents } \\
\text { were/are } \\
\text { friends }\end{array}$ & $\begin{array}{c}\text { Part of the } \\
\text { same group }\end{array}$ & $\begin{array}{c}\text { Gym/Outdoor } \\
\text { activities }\end{array}$ & Club/Organization & Church/Synagogue \\
\hline
\end{tabular}




\section{Appendix D}

\section{Dating Anxiety Survey}

Instructions: For each item below, consider the target person (dating possibility/DP) to be of the gender you would date (i.e., a guy if you are a straight female or a gay male; a girl if you are a lesbian or a straight male; your preferred gender if bi-sexual)

Rate the following situations on the amount of anxiety you feel on a scale from 1 (Least Anxious) to 7 (Most Anxious).

\begin{tabular}{|c|c|c|c|c|c|c|c|}
\hline & $\begin{array}{c}\text { Least } \\
\text { Anxious } \\
\end{array}$ & & & & & & $\begin{array}{c}\text { Most } \\
\text { Anxious }\end{array}$ \\
\hline $\begin{array}{l}\text { 1) Just being around a particularly } \\
\text { good looking DP. }\end{array}$ & 1 & 2 & 3 & 4 & 5 & 6 & 7 \\
\hline $\begin{array}{l}\text { 2) Carrying on a conversation } \\
\text { initiated by a DP on campus. }\end{array}$ & 1 & 2 & 3 & 4 & 5 & 6 & 7 \\
\hline $\begin{array}{l}\text { 3) Talking with some DP you } \\
\text { have known for some time. }\end{array}$ & 1 & 2 & 3 & 4 & 5 & 6 & 7 \\
\hline $\begin{array}{l}\text { 4) Initiating a conversation with a } \\
\text { DP from one of your classes } \\
\text { whom you see on campus. }\end{array}$ & 1 & 2 & 3 & 4 & 5 & 6 & 7 \\
\hline $\begin{array}{l}\text { 5) Sitting next to a DP in class by } \\
\text { your choice of seats. }\end{array}$ & 1 & 2 & 3 & 4 & 5 & 6 & 7 \\
\hline $\begin{array}{l}\text { 6) Being introduced to a new DP } \\
\text { at a party while with a group of } \\
\text { your friends. }\end{array}$ & 1 & 2 & 3 & 4 & 5 & 6 & 7 \\
\hline $\begin{array}{l}\text { 7) Being introduced to a new DP } \\
\text { while with a group of your } \\
\text { friends. }\end{array}$ & 1 & 2 & 3 & 4 & 5 & 6 & 7 \\
\hline $\begin{array}{l}\text { 8) Talking to a DP with a group of } \\
\text { male and female friends. }\end{array}$ & 1 & 2 & 3 & 4 & 5 & 6 & 7 \\
\hline $\begin{array}{l}\text { 9) Calling up a DP about some } \\
\text { classwork. }\end{array}$ & 1 & 2 & 3 & 4 & 5 & 6 & 7 \\
\hline 10)Calling up a DP just to talk. & & & & & & & \\
\hline
\end{tabular}




\begin{tabular}{|c|c|c|c|c|c|c|c|}
\hline & 1 & 2 & 3 & 4 & 5 & 6 & 7 \\
\hline $\begin{array}{l}\text { 11)Asking a DP to have a cup of } \\
\text { coffee with you after class. }\end{array}$ & 1 & 2 & 3 & 4 & 5 & 6 & 7 \\
\hline $\begin{array}{l}\text { 12) Starting a conversation with a } \\
\text { DP whom you have never met } \\
\text { before in a dorm lounge or } \\
\text { cafeteria. }\end{array}$ & 1 & 2 & 3 & 4 & 5 & 6 & 7 \\
\hline $\begin{array}{l}\text { 13)Asking a DP to go to a party } \\
\text { with you. }\end{array}$ & 1 & 2 & 3 & 4 & 5 & 6 & 7 \\
\hline $\begin{array}{l}\text { 14)Beginning a conversation with } \\
\text { an attractive DP whom you } \\
\text { would like to date. }\end{array}$ & 1 & 2 & 3 & 4 & 5 & 6 & 7 \\
\hline $\begin{array}{l}\text { 15)While talking to a DP you like, } \\
\text { trying to communicate that you } \\
\text { would like to go out with him. }\end{array}$ & 1 & 2 & 3 & 4 & 5 & 6 & 7 \\
\hline 16)The setting up of a date. & 1 & 2 & 3 & 4 & 5 & 6 & 7 \\
\hline 17)The initial meeting for the date. & 1 & 2 & 3 & 4 & 5 & 6 & 7 \\
\hline $\begin{array}{l}\text { 18)The first few minutes of } \\
\text { conversation on the date. }\end{array}$ & 1 & 2 & 3 & 4 & 5 & 6 & 7 \\
\hline $\begin{array}{l}\text { 19)Carrying on the conversation } \\
\text { throughout the date. }\end{array}$ & 1 & 2 & 3 & 4 & 5 & 6 & 7 \\
\hline $\begin{array}{l}\text { 20)Trying to make a good } \\
\text { impression while on the date. }\end{array}$ & 1 & 2 & 3 & 4 & 5 & 6 & 7 \\
\hline $\begin{array}{l}\text { 21)Trying not to discern whether } \\
\text { or not your date likes you. }\end{array}$ & 1 & 2 & 3 & 4 & 5 & 6 & 7 \\
\hline 22)First kiss with your date. & 1 & 2 & 3 & 4 & 5 & 6 & 7 \\
\hline $\begin{array}{l}\text { 23)Kissing goodnight at the end of } \\
\text { a date. }\end{array}$ & 1 & 2 & 3 & 4 & 5 & 6 & 7 \\
\hline
\end{tabular}


DP = Dating Possibility

Appendix $E$

The Dating and Assertion Questionnaire

Instructions: For each item below, consider the target person (dating possibility/DP) to be of the gender you would date (i.e., a guy if you are a straight female or a gay male; a girl if you are a lesbian or a straight male; your preferred gender if bi-sexual)

We are interested in finding out something about the likelihood of your acting in certain ways. Below you may find a list of specific behaviors you may or may not exhibit. Use the following rating scale:

$1=$ I never do this

$2=\mid$ sometimes do this

$3=1$ often do this

$4=I$ do this almost always

Now after each of the items on the following list, circle one of the numbers from 1 to 4 which best indicates the likelihood of your behaving in that way. Be as objective as possible.

1) Maintain a long conversation with a DP.

\begin{tabular}{|c|c|c|c|}
\hline 1 & 2 & 3 & 4 \\
\hline
\end{tabular}

2) Get a second date with someone you have dated once.

\begin{tabular}{|c|c|c|c|}
\hline 1 & 2 & 3 & 4 \\
\hline
\end{tabular}

3) Be able to accurately sense how a DP feels about you.

\begin{tabular}{|c|c|c|c|}
\hline 1 & 2 & 3 & 4 \\
\hline
\end{tabular}

4) Have an intimate relationship with a DP.

\begin{tabular}{|c|c|c|c|}
\hline 1 & 2 & 3 & 4 \\
\hline 5 5) Have an intimate physical relationship with a DP. \\
\hline 1 & 2 & 3 & 4 \\
\hline
\end{tabular}

DP = Dating Possibility 
The following questions describe a variety of social situations that you might encounter. In each situation you may feel "put on the spot." Some situations may be familiar to you, and others may not. We'd like you to read each situation and try to imagine yourself actually in the situation. The more vividly you get a mental picture and place yourself into the situation, the better.

After each situation, circle one of the numbers from 1 to 5 which best describes you using the following scale.

1 = I would be so uncomfortable and so unable to handle the situation that I would avoid it if possible.

$2=$ I would feel very uncomfortable and would have a lot of difficulty handling this situation.

$3=$ I would feel somewhat uncomfortable and would have some difficulty handling this situation.

$4=$ I would feel quite comfortable and would be able to handle this situation fairly well. $5=$ I would feel quite comfortable and would be able to handle this situation very well.

1) You have enjoyed this date and would like to see your date again. The evening is coming to a close and you decide to say something.

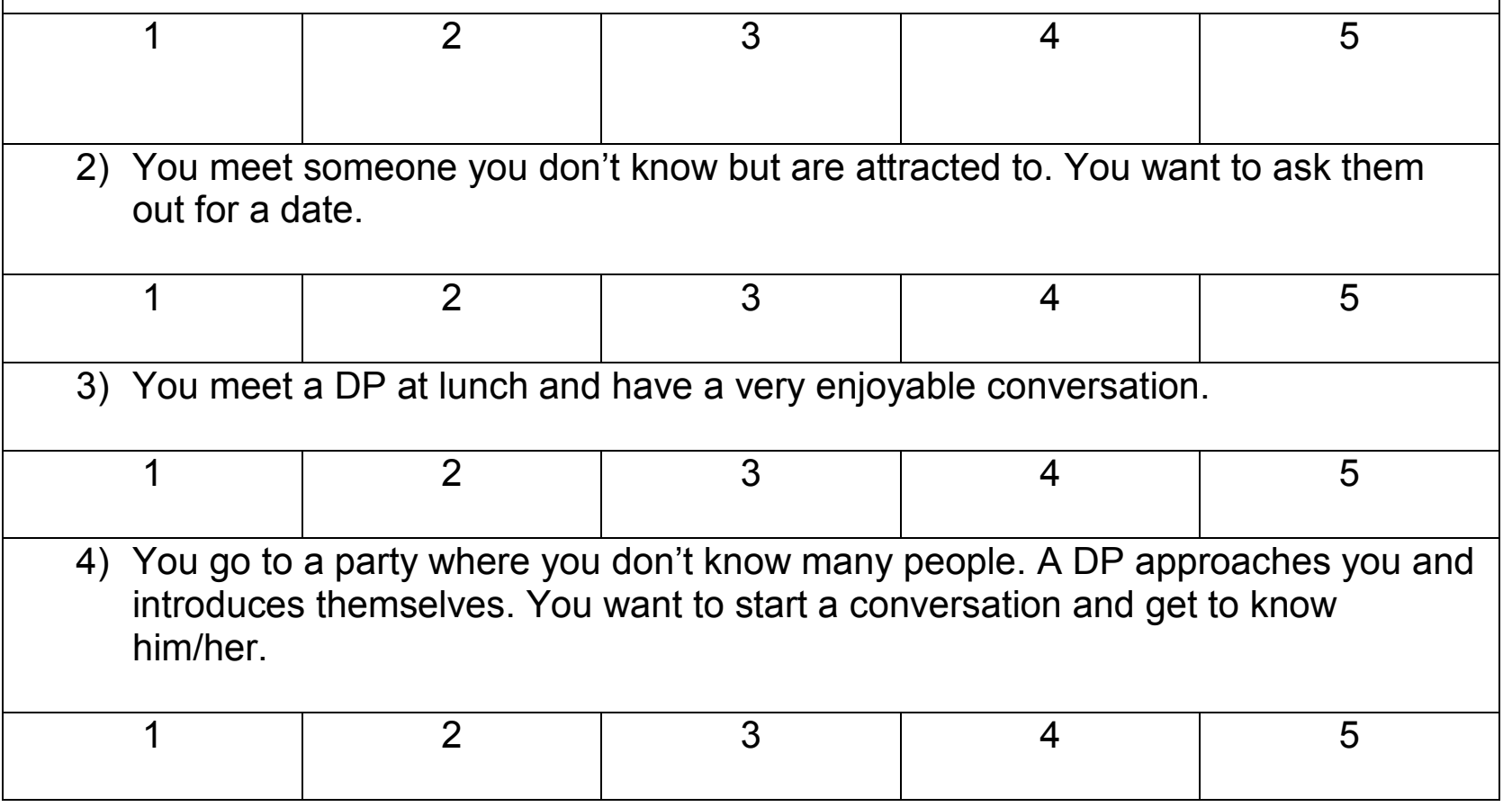

DP = Dating Possibility 